
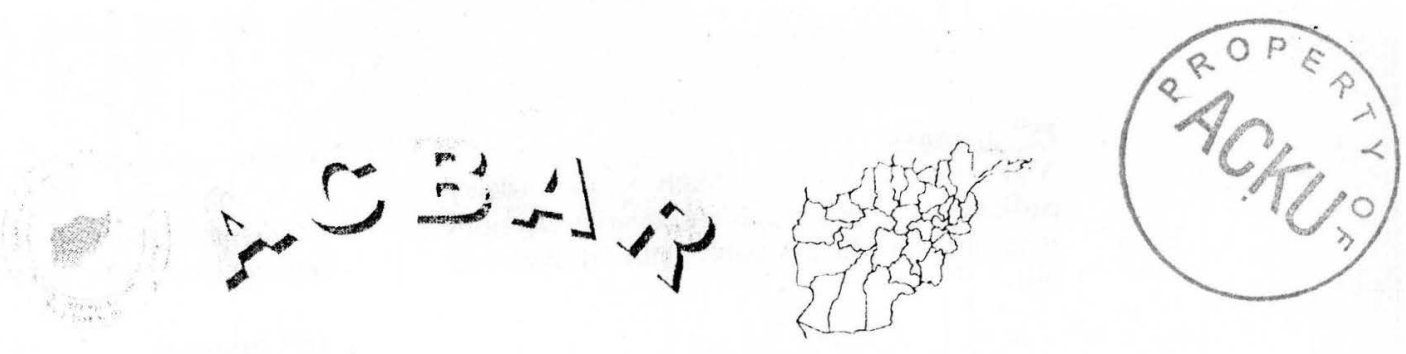

News Summary for January-2005

\section{Aid and Economic Development}

\section{$2^{\text {nd }}$ January}

Despite the enormous amount of international aid being pumped into Afghanistan. some people in the country feel there are few visible signs of improvement. It is estimated that Afghanistan has received nearly 14 billion US dollars in the past three years. (APP)

\section{$7^{\text {th }}$ January}

Aid workers in the capital Kabul have raised concern about the increase in violent attacks on aid agencies over the last couple of month.

\section{$13^{\text {th }}$ January}

The Afghan education ministry is to receive a fund of $\$ 600$ million in foreign aid for developing schools and training teachers. in 2005. ministry officials said. (NNI)

\section{$20^{\text {th }}$ January}

The Asian Development Band said on Wednesday it had approved a 750000)-dollar grant to develop solar energy technology for use in isolated rural areas in Afghanistan.

\section{$21^{\text {st }}$ January}

President Karzai and Iranian President Khatami jointly inaugurated the $122-\mathrm{km}$ HeratIslam Qala highway constructed at the cost of $\$ 60$ million.

(IND)

\section{$31^{\text {st }}$ January}

The Karzai administration would prefer to see international donors fund Afghanistan's development rather than NGOs, which currently receive a lion's share of the aid.

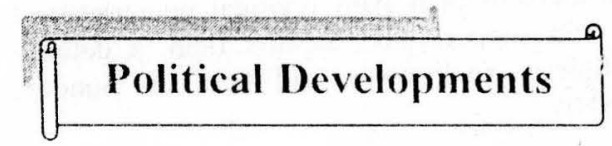

\section{2nd January}

IIS forces commander (ieneral in Afghanistan. David Barno has said talks with the moderate Taliban are in progress. (APP)

Dr. Zeenat Karzai, the wife of President Mamid Karzai told Pazhwak News Agency that she plans to come more inte society working for Afghan women. (APP)

\section{$4^{\text {th }}$ January}

Divisions have opened in the Pentagon over the role that the military should play in an aggressive crackdown on Afghanistan's nacroeconomy amid fears that it could destabilise the country ahead of election due in April.

$(\mathrm{S} \wedge \mathrm{N} \Lambda)$

Abdul Hamid Mubare he former denuty minister of cuiture and information ministry. regards the censorship-oriented policy of the ministry's leadership as the reason of his resignation. but the minister denies this claim. (Online)

The US-led coalition troops are likely to remain in the post-war Afghanistan for decades. a senior US commander hinted here Monday. (NNI)

\section{$7^{\text {th }}$ January}

Pakistan and the United Nations Iligh Commission for Refugees have said that the census of the Afghan refugees living in Pakistan will start next month. (PPI)

\section{$12^{\text {th }}$ January}

Nearly 4.000 women. who are the bread winners for their families will be given johs according to their skills in month s time. said ( $N$ officials. (NNI) 


\section{$25^{\text {th }}$ January}

Afghanistan looks likely to delay parliamentary, provincial and district elections scheduled for May. possibly until fall diplomat say.

\section{Security Matters}

\section{4th January}

The Afghan government favors a security partnership plan with regional countries and would support talks in this field, a defense Ministry spokesman said here on Sunday. (NNI)

The US military in Afghanistan said Monday that one of the eight $A$ fghan detainees who have controversially died in their custody might have been killed by snakebite.?? (APP)

\section{$5^{\text {th }}$ January}

Tow Germans have been injured as a result of an explosion in northern Afghanistan Kunduz. province. (Agency)

According to Radio Tehran, Taliban Spokesman said that the US forces based in Shakar Kala area of Logar province were targeted and killing US soldiers. (Online)

\section{$7^{\text {th }}$ January}

Tens of thousands of irregular militia groups will be disarmed through a new joint United Nation and government. Defense Ministry official told IRIN. (NNI)

\section{$12^{\text {th }}$ January}

An anti-tank mine exploded under a truck near a military base housing Afghan and US troops on Monday killing the driver and wounding three passengers, the American military said. (AP)

The German government is considering increasing the number of its peacekeepers in Afghanistan after a warning by the German Intelligence Service of increased threat to the German force. (Online)

\section{$13^{\text {th }}$ January}

Osama bin Laden and other militant leaders could be hiding in eastern Afghanistan. the commanders of US forces along a key stretch of the Pakistan border told. (AP)

\section{$16^{\text {th }}$ January}

Afghan government has claimed Friday to have disarmed 33,406 members of the Afghanistan Military Forces and entered the reintegration phase. (INP)

\section{$18^{\text {th }}$ January}

More than 200 villagers from rural areas in the northern province of Faryab have fled their homes and sought refuge in the city of Mazar$i$-Sharif, claiming they have been persecuted by a local commander. ( $S \wedge N \wedge$ )

Afghan government has confirmed the killing of six $\Lambda$ fghan police officials in Ilelmand province. (Online)

Taliban Spokesman Monday said heads of the Taliban movement and Jlema Council. after week-long meeting voiced to continue their fight against the US-led coalition forces operating on $A$ fghan soil to their last breath.

For about 20 minutes, the Marines and their unknown attackers exchanged fire just outside a village in northern Khost province. The attackers fled before Cobra Helicopters arrived on scene, leaving one marine wounded. (Online)

\section{$27^{\text {th }}$ January}

NATO is to send more troops to Afghanistan to reinforce security for this year's parliamentary elections. the commander of a NATO-led peacekeping force said on Wednesday. (Reuters)

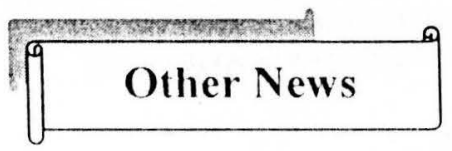

\section{$11^{\text {th }}$ January}

High Commissioner for Refugee Ruud Lubbers leaves next week for a four-day visit to Afghanistan. He will be discussing the reconstruction process can be sustained in order to encourage refugees to return home. (Online)

\section{$12^{\text {th }}$ January}

Women prisoners in the eentral jail. in the city of Mazar-e-Sharif have complained of the lack of health and food in the jail and that the are sexually abused. (NNI)

\section{$13^{\text {th }}$ January}

The Japan International cooperation Agency (JICA) said to launch a three-year project in Kandahar. Balkh and Bamyan prosinees (1) 
enhance women's skills and self-sufficiency by training them in different professions. (NNI)

\section{$16^{\text {th }}$ January}

The provincial government in Herat has banned the publication of weekly "The Payame-Hambastagi" that published an article criticizing government officials. (INP)

Around 45 female prisoners in Kabul prison are protesting what they call their unlawful detention. The burned their blankets and shattered the window panes during the protests. (NNI)

\section{$17^{\text {th }}$ January}

Eighty-one Afghan detainees were released from US custody at Bagram air base near Kabul and turned over to the Afghan Supreme Court Sunday, Government officials said. (AFP)

The UN refugee agency has threatened to suspend aid for Afghan refugees in Iran unless Tehran stopped their forced repatriation. (AFP)

\section{$18^{\text {th }}$ January}

Recent rains in Afghanistan have some people wondering if the drought that has bedeviled the nation for years ending. (Online)

\section{$21^{\text {st }}$ January}

Taliban leader Mullah Omar has rejected negotiations with US-led forces and the Afghan government.

Chairman of the Supreme Court, at a meeting with the UN legal advisor, stressed that the US forces should observe human rights in our country. (IND)

\section{$\underline{27^{\text {th }} \text { January }}$}

A new curriculum for grade 1-4 with significant changes in the teaching method has been finalized by Afghanistan Education Ministry is now ready for publication.

\section{$\underline{31^{\text {st }} \text { January }}$}

Five civilians died and 10 others were seriously hurt Sunday when their vehicle hit a mine. 


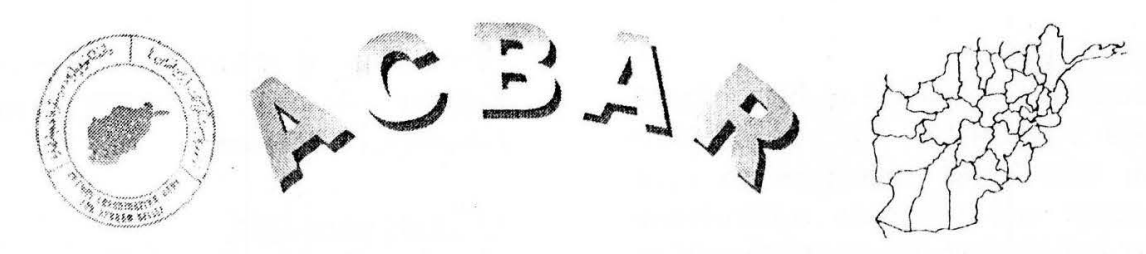

News Summary for February-2005

Aid and Economic Development

\section{$1^{\text {st }}$ February 2005}

The United States has donated 150 million dollars to be spent on poppy eradication. In agreement with the international community, the formers would be economically assisted, and the poppy would be replaced by crops that can be marketed inside the country and can help the farmers improve their economic conditions. (INP)

\section{$2^{\text {nd }}$ February 2005}

The Asian Development Bank (ADB) has fulfilled its pledge of providing 500 million dollars in sort loans and grants to Afghanistan in 2004, the bank announced on Tuesday. (NNI)

\section{$2^{\text {nd }}$ February 2005}

The World Bank has approved a $\$ 27$ million grant for Afghanistan to strengthen government administration, public procurement and financial and accountability systems. (NNI)

\section{$3^{\text {rd }}$ February 2005}

Higher education in Afghanistan is expected to be revamped with international funding of $\$ 250$ million after donors meet with the Ministry to discuss the Ministry's budget. The Ministry plans to review curriculum, launching administrative reforms and reconstruction. (NNI)

\section{$4^{\text {th }}$ February 2005}

The first-ever exhibition of construction materials of construction materials and power plant installations and equipment is to be held in the Afghanistan capital Kabul. The exhibition is being arranged by the joint collaboration of Iran's Ministry of Energy and Afghanistan's Ministry of Commerce, Energy, Transportation and Industries. (INP)

\section{$6^{\text {th }}$ February 2005}

President Hamid Karzai had a telephonic conversation 'with James Wolfensohn, president of the World Bank and called for further cooperation by the WB in fighting narcotics. (Agencies)

\section{$9^{\text {th }}$ February 2005}

IMF in its findings declared Afghanistan's overall performance as strong during the third quarter. (APP)

\section{$11^{\text {th }}$ February 2005}

Mercy International will pay $\$ 1,500$ to each farmer of the Nangarhar province who have eradicated poppy from their forms. The Province has eradicated $99 \%$ of its poppy according to provincial officials. (NNI)

\section{$12^{\text {th }}$ February 2005}

The EU set aside about eight millions crowns (about 340,000 dollars) for the joint CzechAfghan project "Breaking the Circle", which is to modernize the center for drug-addicts and improve their treatment, launched in Kabul. (NNI)

\section{$12^{\text {th }}$ February 2005}

South Korea offered to rebuild Naghlu hydroelectric dam and the power line linking Hayratan (on the Uzbek Afghan border) and the town of Pol-e Khomri in the Baghlan Province. (Agencies)

\section{$13^{\text {th }}$ February 2005}

Pakistan and Afghanistan agreed to double level of bilateral traded exceeding USS 1 billion this year. (PPI))

\section{$16^{\text {th }}$ February 2005}

Iran plans to construct a railway line linking it to Pakistan through Afghanistan. (Correspondent) 


\section{$25^{\text {th }}$ February 2005}

India has renewed its pledge to help rebuild war-ravaged Afghanistan and signed two accords to help Kabul strengthen its civil aviation sector and television transmission technology. India would provide $\$ 400$ million to Afghanistan in form of economic and technical assistance. (Agencies)

\section{$25^{\text {th }}$ February 2005}

Netherlands based NGO Health Net International (HNI) donated a modern thermotherapy machine for Leishmania disease to the largest treatment center at the general hospital in northern Balkh Province. (Correspondent)

\section{Political Developments}

\section{$2^{\text {nd }}$ February 2005}

Afghan Presideni Hamid Karzai's spokesman admitted Tuesday that parliamentary elections which are scheduled in to be held before the end of May may be delayed. (APP)

\section{$4^{\text {th }}$ February 2005}

Government of Afghanistan objects to a recent statement attributed to $\mathrm{Mr}$. Antonio Maria Costa, the chief of UNODC, proposing international aid to Afghanistan to be conditional upon eliminating poppy cultivation. (NNI)

\section{$5^{\text {th }}$ February 2005}

The governors of four eastern provinces formed an Economic Coordination Council at a two-day seminar, with five representatives from each province. It was also decided that these provinces would form a 200-members force to safeguard economic institutions. (NNI)

\section{$9^{\text {th }}$ February 2005}

Afghanistan has welcomed an agreement on the surrender of a Taliban-linked commander to the Pakistani authorities, terming it a step towards the stability and security of both countries. (Correspondent)

\section{$11^{\text {th }}$ February 2005}

A census to record vital information about Afghan refugees who arrived in Pakistan after December 1, 1979 will be conducted by the government of Pakistan assisted by the UN Refugee Agency (UNHCR) starting 23 February. (F.P Report)

\section{$13^{\text {th }}$ February 2005}

The minister of refugee affairs denies having signed an agreement on the forced repatriation of 16,000 Afglan refugees living in Germany. (INP)

\section{$14^{\text {th }}$ February 2005}

NATO urged Afghanistan to fix a date for parliamentary elections as soon as possible to give the alliance time to plan reinforcements to send to the country for the vote. (Agencies)

\section{$15^{\text {th }}$ February 2005}

President Hamid Karzai's attempts to reform and streamline the country's government by weeding out incompetent or unqualified civil servants have met with mixed response from government employees. (SANA)

\section{$16^{\text {th }}$ February 2005}

The US ambassador to Afghanistan Zalmay Khalilzad told that many senior Taliban members have agreed to join a reconciliation process to be announced soon by the Afghan government. (SANA)

\section{$18^{\text {th }}$ February 2005}

UNICR will resume its voluntary repatriation program from March 7 for Afghan refugees who wish to go home from Pakistan, stated in a press release. (SANA)

\section{$18^{\text {th }}$ February 2005}

The world food program has rushed food supplies to the southern province of Zabul which was facing a food shortage after most of the district was cut off due to heavy snowfall. (Correspondent)

\section{$20^{\text {th }}$ February 2005}

Prime Minister Shaukat Aziz and Afghan President Hamid Karzai discussed the transAfghanistan gas pipeline project at a meeting in Jeddah. They agreed on further cooperation to develop the region together with the Central Asian States. (APP)

\section{$23^{\text {rd }}$ February 2005}

A senior American lawmaker Sen. John McCain called for permanent US bases in Afghanistan to safeguard American security interests in the region. (Agencies)

\section{$27^{\text {th }}$ February 2005}

Afghanistan President Hamid Karzai said his country wanted to join the South Asian 
Association for Regional Cooperation (SAARC) and become a link between the regional grouping and Central Asia. (AFP)

\section{$27^{\text {th }}$ February 2005}

Ms Habiba Sarabi, Afghanistan's former women's minister is set to be appointed governor by President Hamid Karzai that would make her the country's first female provincial governor. (PPI)

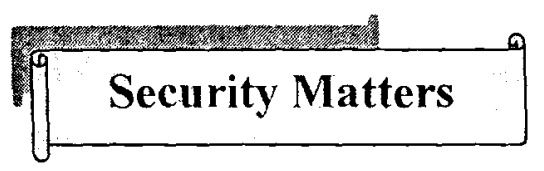

\section{$1^{\text {st }}$ February 2005}

Two suspected insurgents were killed when a bomb they were trying to plant on a key highway that links the eastern city of Jalalabad to Kunar province exploded. (Reuters)

\section{$12^{\text {th }}$ February 2005}

A soldier belonging to the French contingent of the NATO-led force in Afghanistan killed himself in Kabul. It was the first know suicide by a soldier from the ISAF in Afghanistan. (AFP)

\section{$18^{\text {th }}$ February 2005}

A local United Nation worker was killed by robbers who then buried the body in an aid agency compound. (INP)

\section{$19^{\text {th }}$ February 2005}

Aid workers and officials sounded alarm bells over a looming humanitarian crisis in western Afghanistan saying they feared up to 1,000 children may have died during severe winter weather. (AFP)

\section{$22^{\text {nd }}$ February 2005}

The Kandahar branch of the Pashtany Tejaraty bank was looted of 30 million Afs by robbers. Police suspect the involvement of bank guards who are absconding. (Correspondent)

\section{$25^{\text {th }}$ February 2005}

Two Afghan aid workers that belonged to IbnSina were found shot dead in Maiwand district of Kandahar province in a fresh blow to aid and reconstruction efforts. (ONLINE)

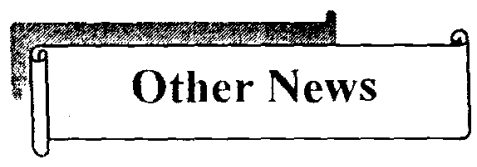

\section{$1^{\text {st }}$ February 2005}

Turkish troops took responsibility for Afghanistan's international airport Monday as NATO prepares to expand its security mission in the still unstable country. (AP)

\section{$2^{\text {nd }}$ February 2005}

Iran has agreed to extend the date for the return of Afghan refugees as a result of the talks held during the recent visit of President Hanid Karzai to Iran. (Correspondent)

\section{$2^{\text {"nd }}$ February 2005}

Executive Director of the UN Office on Drugs and Crime (UNODC) Antonio Maria Costa has urged Afghanistan to take tough measures against drug traffickers, according to a statement Tuesday. (Agencies)

\section{$2^{\text {nd }}$ February 2005}

US-backed efforts to eradicate $\Lambda$ fghan opium poppy fields could backfire, by stirring up instability and enriching powerful drug lords, some 30 non-governmental organizations said in an open letter on Tuesday. (Reuters)

\section{$3^{\text {rd }}$ February 2005}

The Voice of Afghan Women, an $A$ fghan radio station devoted to the interests of women, has been re-launched in Afghanistan. (INP)

\section{$3^{\text {ril }}$ February 2005}

Iran handed over 276 Afghans who were released from Iranian jails to Afghan authorities on the joint Iran Afghanistan border in Herat. (PAN)

\section{$4^{\text {th }}$ February 2005}

A week of unseasonably cold weather and an out break of whooping cough have killed 38 people in Afghanistan's rugged and remote provinces. (Reuters)

\section{$5^{\text {th }}$ February 2005}

An Afghan passenger jet that went missing in a snow storm with 104 people including at least 15 foreigners on board on $3^{\text {rd }}$ February. Later on Saturday, the wreckage of the jet was found in mountains east of Kabul with all 104 people died. (ONLINE)

\section{$8^{\text {th }}$ February 2005}

According to a report issued by the World Health Organization (WHO) the number of polio cases has dropped by 45 percent in 
Afghanistan, India and Pakistan, the three countries on the Asian continent that still have the disease. (ONLINE)

\section{$8^{\text {th }}$ February 2005}

After the last year's dramatic increase of opium production in Afghanistan, the government has implemented an aggressive strategy to eradicate poppy cultivation. The new government has labeled the year 2005 as "Poppy Eradication Year". (SANA)

\section{$24^{\text {th }}$ February 2005}

A number of people living in the Afghan capital Kabul claim that the process in getting national identity cards is impeded and delayed due to what they term as corrupt officials working in the issuing departments, who demand bribes. (PAN)

\section{$23^{\text {rd }}$ February 2005}

Afghanistan has made remarkable progress since the demise of the Taliban government in late $200 \mathrm{I}$, but the fragile nation could easily slip into chaos and object poverty. The conclusion was drawn by the United Nations Development Program which released a report on the subject. (ONLINE) 


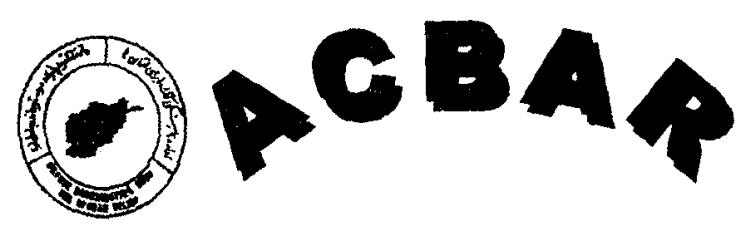

News Summary for March-2005

\section{Aid and Economic Development}

\section{$1^{\text {st }}$ March}

A meeting was held at Dubai Chamber of Commerce \& Industry (DCCI) to discuss bilateral economic and commercial relations between Dubai and Afghanistan. (NNI)

Afghanistan president Hamid Karzai has told India taken up with Islamabad the issue of a trade corridor from India passing through Pakistan. The Afghan President expressed interest in getting more Indian teachers and doctors to Afghanistan and India promised to continue their assistance with Afghanistan. (New Delhi NNI)

\section{$4^{\text {th }}$ March}

Germany has earmarked almost 400,000 euros in humanitarian aid to help Afghanistan through one of its worst winters in recent times. (AFP)

\section{$5^{\text {th }}$ March}

United States is contributing $\$ 100,000$ in emergency assistance to alleviate suffering caused by unusually heavy snowfall in Afghanistan. (Online)

\section{March}

Japan threw a lifeline to Afghanistan's disarmament process, giving $\$ 29 \mathrm{~m}$ to a UN-led Afghan News Beginning Program that aims I disarm and offer new careers to 50,000 soldiers. (PPI)

\section{8 $^{\text {th }}$ March}

The Afghan Red Crescent Society (ARCS) has pledged US\$ 30,000 that it received from the Chinese embassy in Kabul for flood victims in Afghanistan. (PAN)

\section{1 th $^{\text {March }}$}

Canada will give five million dollars (3.7 million euros) to a program designed to rebuild a judiciary system in Afghanistan. (Online)

\section{$12^{\text {th }}$ March}

Volume of Afghanistan and Iran's transaction has reached $\$ 260$ million in a year. (NNI)

\section{$13^{\text {th }}$ March}

The US is providing $\$ 2.5$ million to Afghanistan for projects aimed at developing the social status of Afghan women. (Online)

\section{4" March}

The US ambassador to Afghanistan is urging congress to approve $\$ 5$ billion in additional to a country that was shattered by wars and terrorism but now is making major progress toward peace and democracy. (NNI)

\section{$15^{\text {th }}$ March}

Afghanistan's finance minister Anwar-ul-Haq Ahadi said that Iran has pledged to provide the war ravaged country with financial assistance of $\$ 50 \mathrm{mln}$ in the year to March 2006. (NNI)

The World Food Program (WFP) distributed 45 metric tons of foodstuffs to 822 Afghan nomadic Kuchi families in the southern Kandahar on Monday. (PAN)

\section{$16^{\text {th }}$ March}

USAID has announced \$2.5 million grant to the Afghanistan Ministry of women's affair. (APP)

A joint delegation of the United Nation Assistance Mission for Afghanistan UNAMA, UN Children Fund Program and WFP has started distributing foodstuff and other materials to over 1000 families affected by flood. (NNI)

\section{$18^{\text {th }}$ March}

Afghan government has announced its first budget of thirty-two thousand millions Afghanis worth 680 million S US dollars. (Online)

\section{$22^{\text {ed }}$ March}

The ministry of economy is optimistic about 
the rate of growth for Afghanistan in the following fiscal year, predicting $11 \%$ growth rate. (PAN)

\section{4t March}

The education Ministry has sought US $\$ 490$ million for its development plans for the year 2005-2006. (NNI)

\section{$26^{\text {th }}$ March}

Japan is donating $\$ 12 \mathrm{~m}$ in addition to that country's previous aid, for the reconstruction of Afghanistan. (NNI)

\section{March}

The US department of agriculture announced that it would denote 23000 metric tones of crude seeds of soybean oil to the government of Afghanistan(NNI)

\section{Political Developments}

\section{$1^{\text {t March }}$}

The US has acquired about more than 36000 square yards of land in Kabul across the present embassy to expand its diplomatic policy in Afghanistan. Envoy and ambassador of Afghanistan Zalmay Khalailzad through year 2056 for 50 years signed the lease and the US embassy didn't say why it acquired the lands. (NNI)

\section{$2^{\text {ed }}$ March}

President Hamid Karzai has appointed General Abdul Rashid Dostum, a feared Afghan warlord who ran against him for the presidency, to head the country's fledgling army.

\begin{abstract}
Afghan officials have announced the postponement of the country's first parliamentary election, which were earlier scheduled to be held by May $20^{\text {th }}$ this year. Afghan Independent Election Commission didn't give any dates for a new schedule.
\end{abstract}

\section{4" March}

Human Rights groups reacted with dismay to Afghan president Hamid Karzai's decision to appoint a controversial regional strongman implicated in numerous rights abuses as his personal military chief of staff. (PPI)

Ms Habiba Surabi has been appointed Governor in Afghanistan. She is the first woman governor in Afghanistan.

\section{$5^{\text {th }}$ March}

The UN Assistance Mission in Afghanistan has appointed four international officials to join the Afghan electoral commission preparing parliamentary and local elections this year. (Online)

\section{$6^{\text {th }}$ March}

Afghanistan's delayed parliamentary elections are likely to be held on Sep $17^{\text {th }}$. (PPI)

\section{$10^{\text {th }}$ March}

Afghan president Hamid Karzai left Wednesday to attend a terrorism conference in Spain and hold talks with the Spanish government. (APP)

\section{2 ${ }^{\text {th }}$ March}

US president George W. Bush plans to name Zalmai Khalilzad, his ambassador in Afghanistan and long tome national security advisor, as the new US ambassador in Iraq. (Reuters)

\section{$23^{\text {rd }}$ March}

The leaders of Afghanistan and Pakistan agreed at talks Tuesday to boost cooperation in the fight against terrorism and drugs, and promoting trade and tourism. (AFP)

The United Nations said the decision to put off Afghanistan's long delayed parliamentary elections until September had advantages in preparing for the polls. (APP)

\section{March}

President Hamid Karzai received a parliamentary delegation of NATO countries at the presidential palace. (NNI)

Russia's justice minister Yuri Chaika and Afghanistan's special envoy to the Russian federation signed an extradition treaty in Moscow. (PPI)

Registration of candidates for the forthcoming parliamentary elections will start on 26 April and continue for three weeks allover Afghanistan. (NNI)

\section{9" March}

The United States is pending US\$83 million to upgrade its two main air bases in Afghanistan, an Air Force general said the latest indication that the American forces will remain in Afghanistan for years. (APP) 


\section{$31^{\text {st }}$ March}

The US foundation signed a great agreement with the US agency for international development to serve as a fiduciary agent for the newly established American University of Afghanistan in Kabul. (Online)

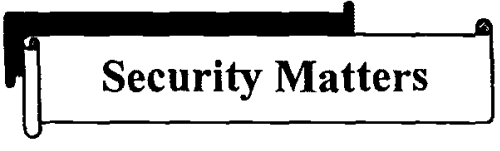

$1^{\text {st }}$ March

A car bomb exploded outside a government building in restive province of southern Afghanistan on Monday, wounding three policemen. One of them was seriously injured

An oil tanker carrying fuel to the Bagram Air base exploded on the way to the base in Mahipar area east of Kabul but no one was hurt in the blast though the explosion spread the fuel to a distance of ten meters. (SANA)

At least three Afghan policemen were wounded as the vehicle they were traveling in run over a landmine in the troubled Helmand province. (Online)

\section{$3^{\text {rd }}$ March}

Afghan security forces have arrested four ranking members of the Taliban in the country's southeast, where remnants of the ousted regime continued to wage a violent revolt. (AFP)

A young boy and his sister were shot and injured by a local commander who objected to the marriage of the young boy. (INP)

Italian soldiers have begun arriving in western Afghanistan under plans for NATO troops to gradually relieve US forces across the country. (AP)

NATO on Wednesday began a long awaited expansion of its peacekeeping forces into western of Afghanistan as a part of effort to rebuild the remote and rugged region. (AFP)

\section{$\underline{5^{\text {th }} \text { March }}$}

Afghan military intelligence agents arrested a foreign national at Kabul airport this week, and they suspected he was plotting terrorist attack. (AP)

The ClA inspector general is investigating why an afghan prisoner was allowed to freeze to death in the agency's custody. (Online)

\section{March}

The prosecution department of the general intelligence directorate in the capital said they were hoping for the harshest possible sentencing for Shirin Gul a 39 years old woman accused of killing 35 drivers with the help of five other accomplices. (Agencies)

\section{1" March}

Government officials and human rights activists have been alarmed at the increasing number of child kidnapping in southern Kandahar. (NNI)

Troops of the Afghan National Army have arrested 15 suspected terrorists in the troubled east and southern provinces over the past two weeks. (NNI)

The chief of Arghandab District in the Southern Zabul province and his two guards were injured in a clash in Shahjoy District. (NNI)

\section{$16^{\text {th }}$ March}

An Afghan soldier was killed and another wounded in a mine explosion while searching for bodies from a plane, which crashed in to a mountain peak. (AFP)

Senior US officials have warned in recent weeks that Al-Qaeda is regrouping of another massive attack, its agent's bent on acquiring nuclear, chemical or biological weapons. (AFP)

The Talibans' spokesman said that they killed one district policeman and raided government compound in eastern Laghman province Monday night. (PAN)

The nomad Kuchi people of Laghman province claimed that provincial security officials have arrested 50 members of the tribe, alleging they assaulted government officials, but security officials denied this claim. (PAN)

\section{$17^{\text {th }}$ March}

Afghan intelligence officers in the southern province of Kandahar Wednesday claimed having arrested members of two armed gangs allegedly involved in child abduction. 
A US soldier died and four others were wounded in a landmine blast in Afghanistan (AFP)

\section{$18^{\text {th }}$ March}

Five people were killed and more than 32 injured in a bomb explosion in former Taliban strong hold of Kandahar on Thursday.

Two people were sentenced to 20 years in prison for the rape of a 12-year-old girl from Kunduz six months ago. (PAN)

\section{$19^{\text {th }}$ March}

Afghan police have arrested a suspect in a bombing that killed five people and injured more than 30 in the southern city of Kandahar. (Agencies)

US military officials have increased the number of suspected homicides of prisoners in Iraq and Afghanistan to 26. (Online)

Police shot dead a villager in remote southeastern Afghanistan during a protest over the murder of a local man and his wife who were working as doctors. (AFP)

\section{March}

Afghan security personnel have defused six bombs in Balkh province other day, which were planned to get exploded on Nowroz. (Online)

\section{$23^{\text {rd }}$ March}

One prisoner has been killed and six people including three policemen injured during a clash at a jail in southern Afghanistan. (AFP)

The interior ministry said police rescued on Sunday an Iranian national who was kidnapped in western province of Farah nearly three months ago one person has been arrested in this connection. (PAN)

\section{$24^{\text {th }}$ March}

US, led troops accidentally shot to death an Afghan boy during a search operation in eastern Afghanistan. (AP)

A terror suspect held in Guantanamo Cuba was a commander for Osama Bin Laden during the Soviet occupation of Afghanistan in the 1980s. (Online)

US led coalition forces said on Wednesday they had killed five suspected Taliban insurgents in a bombing while beating back an over night attack on an American military base in Khost province.

\section{$\mathbf{2 5}^{\text {th }}$ March}

A Taliban militant was killed in a firefight with US led forces in southeast Afghanistan along with another six people including 5 children and one woman. (AFP)

\section{$27^{\text {th }}$ March}

Four US soldiers were killed in a mine blast in the southeastern Afghan province of Logar on Saturday morning.

(AFP)

\section{$28^{\text {th }}$ March}

Students against university administration injured eight students including two females and two policemen during the protest stage.

\section{9 $9^{\text {th }}$ March}

A roadside explosion hit the Canadian Embassy vehicle in the Afghan capital on Monday, wounding one Canadian passenger. Witness said Afghan civilians were also hurt. (AP)

The US military says 27 detainees who died in US custody in Afghanistan between 2002 and 2004 were the victims of homicide or suspected homicide. (Online)

Four suspects will be taken to the court here Tuesday, charged with helping assassinate Afghan leader Ahmad Shah Masoud. (NNI)

\section{0' March}

Afghan police have arrested a man in connection with bomb blast in Kabul, which hit a Canadian diplomatic car, injuring four people including one Canadian. (AFP)

Taliban claimed to have fired rockets at the US bases in Afghanistan. (Online)

Attackers using bombs and guns ambushed US and Afghan government troops Tuesday in region of the country rife with Taliban militants, wounding six Afghan and two American soldiers. (Agencies)

\section{1" March}

Taliban's militants attacked a checkpoint in western Afghanistan, fatally wounding five Afghan soldiers and killing a car driver. (AP 


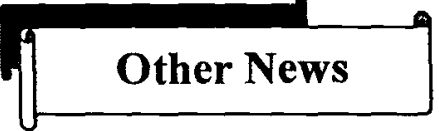

$1^{\text {st }}$ March

Afghan National Army has reached 20000. They have been trained by the US army to fight in the front line against the Taliban and more will be trained in coming future. (PPI)

\section{$3^{\text {rd }}$ March}

UN has claimed that Afghanistan is in danger of becoming a narcotic state after producing its largest annual crops of heroin since the overthrow of Taliban rule. (Online)

\section{$4^{\text {th }}$ March}

The UN refugee agency on $7^{\text {th }}$ March will resume its voluntary repatriation program to assist Afghan refugees in returning to their homeland. (Online)

\section{$6^{\text {th }}$ March}

India has supported Afghanistan's membership in South Asian Association for Regional Cooperation (SAARC). (Online)

\section{$7^{\text {th }}$ March}

The United Nations is to resume repatriations of Afghan refugees from Pakistan on Monday after a winter break, with about 400,000 expected to return this year. (AFP)

\section{$8^{\text {th }}$ March}

Heavy rains triggered floods in remote western Afghanistan that killed at least three people and destroyed some 300 houses. (AFP)

Shortage of the anti rabies vaccine in Heart province has resulted in the deaths of several persons including three children recently.

Four tones of antique coins and $500 \mathrm{~kg}$ of gold jewelry and a number of historical artifacts were smuggled out of Afghanistan to Pakistan between 1992-94 according to leading archeologists. (INP)

\section{$11^{\text {th }}$ March}

Heavy floods killed several people and left more than a thousand houses destroyed in two districts of the western province of Farah.

\section{2 ${ }^{\text {th }}$ March}

Wolves descending from the hills to escape hunger in the country's worst winter in 15 years have killed at least 6 people in remote Afghan villages. (Online)
Afghanistan is undertaking an education program to provide schooling this year for 500,000 girls who were prevented from attending schools under the Taliban regime. (PPI)

\section{$13^{\text {th }}$ March}

Dutch prosecutors accused Hessamuddin Hesam and Habibullah Jalalzai of committing war crimes. (Agencies)

\section{$14^{\text {th }}$ March}

Turkish army Chief Hilmi Ozkok agreed to train Afghan soldiers. (NNI)

\section{March}

The bodies of all victims of the Kam airplane crash have been recovered from then crash site and transferred to Kabul. (PAN)

\section{0"th March}

Severe floods across much of Afghanistan have killed at least 88 people and left thousands homeless. (AFP)

Indian airlines (IA) announced 28 new flights a week as part of expanding its operations to Southeast Asian destination from March $27^{\text {th }}$. (Online) 


\section{OrcBat}

News Summary for April-2005

\section{Aid and Economic Development}

\section{$\mathbf{2}^{\text {md }}$ April}

Australia is providing $\$ 9.2$ million aid for Afghanistan's reconstruction. (NNI)

The NATO -led international security assistance force (ISAF) is going to help Afghan government ensure security for the upcoming legislative polls in the post-Taliban nation. (NNI)

The ministry of refugees and returnees is to distribute plots of lands to 10,000 homeless families who have returned from Iran and Pakistan in the northern province of Baghlan. (NNI)

The Asian development Bank will help improve telecommunication in Afghanistan through a 35 million US dollars loan signed Wedinesday in Kabul to finance the nationwide expansion and upgrading the country's leading cellular network. (NNI)

The Afghan government on Sunday approved spending of US\$4.75 billion over the next year, critical funds for the country's slow recovery provided almost entirely by foreign donors. (Agencies)

\section{3rd April}

The ministry of finance has announced the standard budget for 1384 at a time when, according to government officials, most ministries and other governmental institutions failed to spend last year's development budget.

\section{4th April}

The third international conference focused on Afghanistan's economic development city from Monday leading donors announced here on Sunday. Three days event is aimed at winning more aid for the economic development.

\section{7th April}

Australia is contributing a further $\$ 12$ million to Afghanistan to help with elections and support services, including health and education. (Online)

\section{9th April}

Afghanistan secured US $\$ 80$ million loan from the Asian Development Bank to rebuild a road central to effort to revive is war-shattered economy. (PPI)

\section{$10^{\text {th }}$ April}

Pakistan has donated 10 ambulances to Afghanistan. These vehicles were handed over to Afghan authorities at a ceremony here on Saturday. (PPI)

\section{$15^{\text {th }}$ Aoril}

The Asian development bank has approved a $\$ 50$ million assistance package for a power supply improvement project in rural Afghanistan. (AFP)

\section{$16^{\text {th }}$ April}

The Asian Development Bank said on Thursday that it was lending $\$ 35$ million to Afghanistan to improve its wireless telephone network. (Agencies)

\section{April}

Less than a quarter of the money required for the conduct of the parliamentary election has been collected so far, the joint electoral management board said. The JEMB said \$36 million of the required budget of $\$ 148$ million had been collected. (PAN)

\section{0th April}

35 of the 100 Hino buses Islamabad has donated to Kabul will reach to Afghanistan next week.

\section{1: April}

The Turkish Prime Minister Recep Tayyip Erdogan during a two days visit to the capital Kabul signed an agreement with Afghan president Hamid Karzai to build schools and hospitals. 


\section{2 $^{\text {ed }}$ April}

Pakistan and Afghanistan will achieve US \$1 billion mark of bilateral trade this year and it is expected to further improve by opening new rail and road links between the two states.

\section{5 ${ }^{\text {th }}$ April}

German economy minister Wolfgang Clement and his visiting Afghan counter part Hedayat Amin Arsalan signed here on Wednesday an agreement on investment protection in Afghanistan. (Online)

\section{$27^{\text {th }}$ April}

The Japanese government has provided aid worth $\$ 125,000$ to the Afghan government.

\section{9.th Anril}

Chinese vice president has reaffirmed his country's strong support for Afghanistan's economic recovery during a meeting with visiting Vice President Abdul Karim Khalil. (SANA)

\section{Political Developments}

\section{3rd April}

A dozen opposition political parties have formed alliance to ensure more seats in the upcoming Parliamentary elections. (NNI)

General Rashid Dostum would stand down as Junbish-e-Milli chief in a couple of months, a close confident of warlord revealed on Sunday.

\section{7 th April}

US ambassador of Afghanistan Zalmay Khalilzad has been chosen to become the US envoy to Iraq as US forces grapple with a bloody insurgency and Iraqi politicians struggle to form a government. (Reuters)

\section{2th April}

Afghan Defence Minister Abdur Rahim Wardak has reiterated Kabul's desire to reach long-term military and political arrangements with the United States.

\section{4th April}

Afghanistan's top election official said Afghan refugees living in neighboring Iran and Pakistan would have no chance to vote in the upcoming Afghan parliamentary elections. (NNI)

\section{$15^{\text {th }}$ April}

Al-Qaeda's former finance manager Dr Aminul Haq has ruled out any negotiations with the US-backed Afghan government led by president Hamid Karzai. (NNI)

$17^{\text {th }}$ April

The exports to Afghanistan via Torkham have risen to over Rs. 6 billion during the first two quarters of the current fiscal, showing an increase of 150 percent. (APP)

\section{$19^{\text {th }}$ April}

Afghan warlord Abdul Rashid Dostum officially joined president Hamid Karzai's administration Monday after stepping down as chief of his feared northern militia faction. (APP)

\section{$22^{\text {and }}$ April}

The British Prime Minister's special envoy, General John McColl will visit several provinces in Afghanistan to renew Britain's long-term commitments to Afghanistan and improve bilateral ties. (NNI)

\section{6" April}

Selection of candidates for the parliamentary elections will be one of the most difficult phases of the election for officials.

\section{$28^{\text {th }}$ April}

Afghan and UN officials presented the rules Monday for candidates in the country's first parliamentary elections since the fall of Taliban.

\section{9th April}

UN secretary Kofi Anan has backed an extension of The United Nations mandate in Afghanistan beyond next March. (Online)

\section{0"t April}

The upcoming Afghan parliament would take decision on the proposed plan of long-term security partnership with the United States, president Hamid Karzai announced. (NNI)

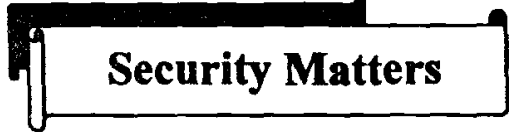

\section{1*April}

US military officials in Afghanistan have said that two of their troops have been wounded in attack in Uruzgan. (Online)

\section{2nd April}

A search and recovery operation is underway Thursday to find bodies of two missing US American military helicopter crash in Afghanistan left at least 16 people dead. (AFP) 
Coalition forces with the help Afghan soldiers raided a suspected Taliban hideout in southern Afghanistan and arrested three original rebel commanders after they surrendered without fighting. (AP)

\section{3rd April}

Suspected Taliban gunmen ambushed a convoy of civilian trucks carrying vehicles to the US military in southem Afghanistan, killing three of the drivers. (Online)

Four Afghans included two children were killed and five other people were injured in two separate bomb attacks in Afghanistan. (Online)

Seven people have been killed and five injured in two explosions and an ambush of truck supplying fuel to US forces in Afghanistan, marking a surge in a suspected Taliban spring offensive. (Agencies)

\section{4th April}

Taliban militia stormed a government building in southem Afghanistan and killed up to nine Afghan policemen in a two-hour gun battle before fleeing. (AFP)

\section{5th April}

A vehicle belonged to an Indian NGO was damaged in a mine explosion in Zherai district of Kandahar on Monday no causalities were found there. (APP)

\section{6th April}

Troops of Afghan National Army have apprehended three Taliban operatives including a group commander in the troubled southem Uruzgan province. (NNI)

\section{7th April}

At least 16 US servicemen were killed Wednesday afternoon, when a Chinook helicopter crashed near the south Afghan province of Ghazni.

Security officials in northern Balkh district have arrested fourteen people in connection with a mine explosion on the $1^{\text {st }}$ April. (PNA)

An Afghan gunman wanted for the murder of a British development worker and the abduction of three UN staff, was captured today after a gunfight outside the home of Kabul's police chief. (INP)

\section{$8^{\text {th }}$ April}

Gunmen have killed five policemen in southern Afghanistan, the least in a spate of attacks linked to ousted Taliban militants, residents and a foreign security source said on Thursday. (Reuters)

\section{9th April}

Gunmen have killed five policemen in southern Afghanistan, the latest in a spate of attacks linked to ousted Taliban militants. (Online)

\section{0"t April}

Taliban claimed on Saturday they killed several policemen in an attack on their cars in the Shah Agha neighborhood of Kandahar.

The body of 18 Americans killed in the worst helicopter crash in the US-led operation in Afghanistan has been recovered and will be repatriated for identification. (APP)

\section{$11^{\text {th }}$ April}

An American man narrowly escaped from kidnappers who had attacked him and bundled him into the back of a car Sunday in the heart of Afghan capital's embassy district. (AFP)

\section{$12^{\text {th }}$ April}

Twelve suspected Taliban were killed Monday in air strikes by US helicopter gun ships and tank buster jets in southeastern Afghanistan. (AFP)

\section{$13^{\text {th }}$ April}

The Taliban vowed Tuesday to assassinate a former Afghan commander after a failed bid to kill him sparked a US air strike, which officials said killed up to 12 militants. (AFP)

\section{$14^{\text {th }}$ April}

Afghan forces in the war torn country's restive south have arrested nine members of the ousted Taliban regime armed with assault rifles and explosive. (AFP)

\section{$15^{\text {th }}$ April}

Afghan police have arrested three members of a criminal gang wanted for the attempted kidnapping of an American man from Kabul. (Reuters)

\section{$17^{\text {th }}$ April}

Several police officers and militia troops were injured in a serious armed encounter in Lashkargha. (PPI)

\section{$18^{\text {th }}$ April}

At least five people were killed and three others received injuries in an attack of Taliban 
fighters on Pakistani on Pakistani oil tankers at Kandahar province in Afghanistan on Sunday. (Online)

\section{$19^{\text {th }}$ April}

Taliban claimed on Sunday they had killed nine Afghan troops in an attack on their vehicle in Shinkai district of Zabul.

Three drivers suffered burn injuries while five oil tankers were torched in an explosion close to the Kandahar airport on Sunday.

\section{0th April}

Taliban have claimed killing four Afghan soldiers in Uruzgan province. (Online)

The ousted Taliban claim they have killed one Afghan soldier and kidnapped another 8, last night from Shah Wali Kot of southern Kandahar province after heavy fighting.

\section{$22^{\text {nd }}$ April}

American forces have resumed aerial bombardment, shelling the frontier regions of the southeastern province of Khost on the Afghan Pakistan borer with five hundred pound bombs.

\section{$25^{\text {th }}$ April}

Four militants and Afghan soldier were killed in a gunfight near Gayan City in Paktika province in the latest burst of violence along the Afghan Pakistan border. (AFP)

\section{April}

Three Afghan soldiers were killed and another injured in southern Kandahar province on the eve of April $24^{\text {th }}$ when the officers came under attack by unknown gunmen.

\section{$28^{\text {th }}$ April}

Three civilians were injured when US troops fired at their mini-bus after being attacked by a home made bomb in eastern Afghanistan. (APP)

\section{$29^{\text {th }}$ April}

Two Afghan policemen and four Taliban were killed in a rebel attack on a district head quarters in the southern province of Kandahar. (Online)

\section{0"April}

Afghan military forces have killed a key commander of the ousted Taliban militia and captured another important militant in southcentral Afghanistan. (AFP)

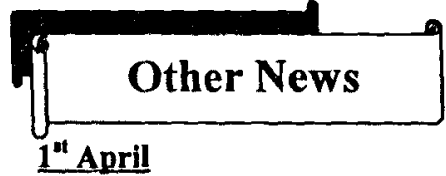

The body of a 25 years old man who was drowned on $27^{\text {th }}$ of March in Kabul River has still not been recovered.

Four suspected radicals went on trail in France for allegedly providing logistical support to the killers of Ahmad Shah Masood. (NNI)

\section{5th April}

More than 1000 acres of farmland has been flooded in Zabul province, whose residents have urged the provincial government to provide them recompense. (PAF)

\section{7th April}

Afghanistan's defence minister gave one of the clearest signs yet that Kabul is open to permanent basing of US forces in the country. (Online)

\section{2th April}

Afghanistan is facing health disaster worse than Tsunami. Around 700 children under the age of five die everyday in Afghanistan due to preventable disease. (SANA)

The United Kingdom has offered to host a meeting of the Afghan Donors in London in order to enhance donors' policies as well as firm up and increase commitments to the government of Afghanistan trust funds, according to the ADF UK statement. (SANA)

$11^{\text {th }}$ April

Re-constructed power station no. 3 was officially inaugurated at a special ceremony in the Chowk-e-Dehmazang area of Kabul city on Sunday. (NNI)

\section{$12^{\text {th }}$ April}

Unusually late cold weather and snow at the end of the worst winter in years have killed 21 children in $\Lambda$ fghanistan. (Reuters)

\section{$14^{\text {th }}$ April}

The US energy association Monday urged Afghanistan to hand over power generation and supply to the private sector to ensure a prompt provision of the facility. (NNI)

\section{$17^{\text {th }}$ April}

Afghan president Hamid Karzai has agreed to send troops of his country to Iraq. According to Mashad Radio, it has been announced 


\section{$18^{\text {1t }}$ April}

Russia on Saturday began pulling out guards from the most dangerous section of the TajikAfghan border as part of a plan to fully withdraw Russian border troops from the exSoviet republic by 2006. (AP)

\section{0th April}

The US has released 17 Afghan detainees from custody at Guantanamo Bay in Cuba and they will be handed to Afghan authorities. (APP)

\section{$21^{\text {st April }}$}

Afghanistan's perilous human rights situation demands ongoing monitoring by the United Nations.

(Online)

\section{2, April}

Afghan independent Human Rights

Commission confirms the existence of private jails and forced marriages and says that the practice has been decreased due to their efforts. (PAN)

\section{$25^{\text {th }}$ April}

The government has approved Rs. 491.54 million for the establishment of Allama Iqbal Faculty of Arts at Kabul University,

Afghanistan. (APP)

\section{$26^{\text {th }}$ Aprll}

UNHCR spokesman Babar Baloch has said that some of the refugees' camps in

Balochistan and NWFP will be closed down.

\section{$28^{\text {th }}$ April}

UNICEF is planning to hold 18 workshops on children's rights in the forth-coming year to educate government officials about children's rights. (NNI)

\section{$29^{\text {th }}$ April}

Iran's airline flagship reopened office in Afghan capital Kabul on Sunday, after a 26year hiatus. 


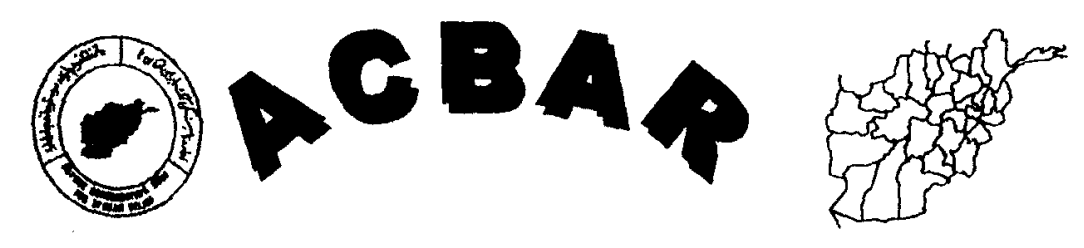

News Summary for May-2005

\section{Aid and Economic Development}

\section{2nd May}

Norway government has donated a large donation of tents to the Afghan National Army. The donation, valued at $\$ 450,000$.

In order to develop its economic influence in Afghanistan Pakistan has announced opening twelve trade routes with Afghanistan for enhancing trade and economic cooperation. (Online)

\section{9th May}

The construction of the 78 kilometers long Kandahar-Arghistan road costing more than $\$ 1$ million started on Sunday, funds for the project will be completed in three months and will be provided from the development budget. (PAN)

\section{$10^{\text {th }}$ May}

About thirteen trucks carrying food items and school stationary as aid from government of Pakistan for Afghanistan were dispatched here on Monday.

\section{$12^{\text {th }}$ May}

The Saudi Arabian government will construct a hospital, a nursing school and playgrounds near the Kabul airport, according to Saudi Ambassador visiting the capital. (NNI)

\section{3th May}

The European Union is one of Afghanistan's largest donors, announced the aid package of 1 billion Euros to the poor state Thursday and pledged more help future. (AP)

\section{$15^{\text {th }}$ May}

Belgian prime minister promised to provide \$1 million for the presidential election and another $\$ 600,000$ for the drug enforcement program. (NNI)

$$
16^{\text {th }} \text { May }
$$

Afghanistan has sought an agreement on investment protection with the UAE in an effort to boost investment in both countries. (PPI)

\section{$17^{\text {th }}$ May}

Britain will hold a donor conference next month to raise funds to help rebuild Afghanistan, foreign secretary Jack Straw said on Monday. (Reuters)

\section{9" May}

The Turkish government had donated \$1 million dollars to the defense ministry in the capital Kabul for reinforcing the Afghan National Army.

The provincial reconstruction team (PRT) in the western city of Heart has delivered medical equipment to the Regional General Hospital in the capital city of Heart. (PAN)

\section{$20^{\text {th }}$ May}

Japan said Wednesday it would grant Afghanistan $28 \$$ million to help build a new international terminal at Kabul's airport which remains dilapidated after more two decades of war. (AFP)

\section{$22^{\text {wd }}$ May}

5 billion rupees are commanded for Pul-eKhumri to Kabul power transmission project that will bring the much-needed Uzbek power for the capital. (Online)

The Afghan government considers consenting foreign telecommunication companies for their network. According to sources two foreign companies who are presently working in the telecom sector of Pakistan have contacted the Afghan authorities for their operations in Afghanistan. (Online)

\section{$23^{\text {rd }}$ May}

The Afghan government plans to use the Tagab Sarobi Road running trough the Kapisa 
province for fruit exports to Pakistan from northern province. (PAN)

\section{$24^{\text {th }}$ May}

The American contingent in the Italian led Provincial Reconstruction Team and US based aid agency Catholic Relief Services on Monday donated $\$ 30,000$ for staving off looming threat posed by locusts westem Heart. (PAN)

\section{$25^{\text {th }}$ May}

According to presidential press office, US promised a mass grant of $\$ 2$ million to rehabilitate and renovate the destroyed and feeble electricity station in Afghanistan. (PAN)

\section{$27^{\text {th }}$ May}

The Customs and income tax department Thursday announced a tax on private and commercial income would be levied from September 23.

An Afghan businessman has donated more than 19 million Afghanis about $(\$ 400,000)$ for a water supply project in a village of Guzra district in the western Heart province, provincial officials said Thursday. (PAN)

\section{$29^{\text {th }}$ May}

Finance minister Anwar - ul-Haq Ahadi hoped on Saturday Afghanistan would receive up to 200 million dollars for the ongoing reconstruction effort.

\section{$30^{\text {th }}$ May}

Afghans and foreigners working in the country are soon going to have start paying tax on their incomes as the aid dependent government strives to increase its revenue.

\section{Political Developments}

$3^{\text {rd }}$ May

Afghan President Hamid Karzai would embark on an important journey from next week to Europe and the United States, a presidential spokesman said Tuesday. (NNI)

\section{$8^{\text {th }}$ May}

President Hamid Karzai begins a 3-day official visit to Brussels and Strasbourg next week for talks with European Union, Belgian and NATO officials. (NNI)

\section{$2^{\text {th }} \mathrm{May}$}

An Afghanistan minister Sunday urged women in her country to participate in this year's national election in big numbers. (AP)

One of president Hamid Karzai's strong critics, Afghanistan National Congress Party (ANCP), has strongly opposed the proposal of establishing US permanent military bases in Afghanistan, a Kabul based weekly reported. (NNI)

$13^{\text {th }}$ May

Afghan president Hamid Karzai has retracted a statement in which he said that all willing Afghan members of the Taliban are eligible for an amnesty offer. (Online)

\section{$14^{\text {th }}$ May}

Javier Solana, European Union high representative for the common foreign and security policy, met with Hamid Karzai, president of Afghanistan, in Brussels and discussed the EU's support for Afghanistan said Solana. (Online)

\section{$18^{\text {th }}$ May}

President Hamid Karzai, scheduled to pay an official visit to the United States next week, is expected to confer with George W. Bush on long- term strategic relations between the two countries.

\section{$22^{\text {ed }}$ May}

Afghan president Hamid Karzai left Kabul Saturday for an official four-day visit to the United States to discuss the US military's role amid fresh allegations of prisoner abuse, as well as reconstruction in the war-torn country. (AFP

US president George W. Bush and Afghanistan's president Hamid Karzai signed a strategic partnership Monday enabling long term American involvement in Afghanistan's security as well as reconstruction. (AFP)

\section{Electoral News}

\section{$10^{\text {th }}$ May}

Tribal elders in the southeastern province of Paktia complain that their allocated number of five seats for the forthcoming parliamentary elections does not accurately represent the population size of the region. (NNI)

Afghan parliamentary candidates will get training to compete for the Wolesi Jirga and the provincial council elections to be held on Sept. 18, officiais said Monday. (NNI) 
$11^{\text {th May }}$

Political parties suggest parliament should decide on the long-term stay of foreign forces and United Nation's role in Afghanistan.

$12^{\text {th }}$ May

Afghan president Hamid Karzai urged the NATO and the international community Wednesday to maintain their presence in Afghanistan after parliamentary elections in September in order to reinforce democracy and security in the country. (AFP)

$15^{\text {th }}$ May

The Joint Election Management Body (JEMB) has appointed a special commission to investigate the alleged threats made on potential candidates nominated for the September parliamentary elections in northern Jowzjan Province. (PAN)

\section{$20^{\text {th }}$ May}

Registration of candidates for the September Afghan parliamentary elections has been extended due to recent civil unrest caused by the violent riots across the country, officials said on Wednesday. (PAN)

\section{1* May}

More than 4000 Afghans including over 300 women have registered their names to run for the upcoming parliamentary polls slated for September 18. (NNI)

A five-day challenging period for Afghan parliamentary candidates has been set to decide if the candidates are qualified for the elections, an official said. (NNI)

\section{3rd May}

Two political parties, including the grand opposition alliance led by Younus Qanooni, have officially registered with the justice ministry for the upcoming parliamentary elections. (NNI)

\section{$24^{\text {th }}$ May}

Final applicants hoping to be national or provincial lawmakers in Afghanistan enrolled Monday to be candidates in September elections, in what was the last day of registration for most parts of the country. (AP)

\section{$30^{\text {th }} \mathrm{May}$}

More than 6,000 candidates have registered for parliamentary and provincial council elections to be held on September 18.

\section{$31^{\text {st }} \mathrm{May}$}

Nearly 3,000 Afghans have registered to stand in a historic September 18 parliamentary elections, the country's election commission said Monday. (Online)

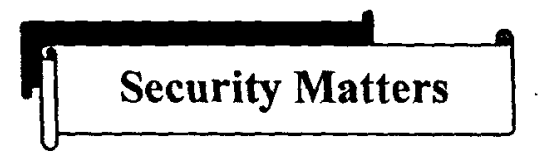

$1^{\text {nt }}$ May

A dispute between Afghan soldiers and police degenerated in to a battle in the western city of Heart and six people were killed, a military official and hospital staff said on Saturday. (Reuters)

Three officials of the interior ministry were killed and two injured in a mine explosion in Mangoi district of the Kunar province on Sunday.

\section{2nd May}

A bomb tore through a jeep carrying Afghan anti drug police in eastern Afghanistan, killing three officers and injuring two more, an official said Sunday. (AP)

Two days of violence triggered between a soldier and a policeman in a western city left three civilians dead and 11 wounded, the defense ministry said on Sunday. (APP)

\section{$3^{\text {rd }}$ May}

Six national army soldiers and two mine clearing workers were wounded in different explosions in Pakitia province on Monday.

Suspected Islamic militants beat to death a mother with her two daughters in northern Afghanistan because they worked for a foreign reconstruction group, officials and western security source said on Monday. (AFP)

\section{$4^{\text {th }}$ May}

Investigators searched Tuesday for the cause of a huge explosion at a warlord's secret underground arms cache in northern Afghanistan as officials said the death toll had risen to 29 and more than 70 people were injured by the blast on Monday. (APP)

\section{$5^{\text {th }}$ May}

A firefight in Afghanistan left about 20 Taliban and one $A$ fghan police officer while six US servicemen and five policemen were injured in Zabul province. (AFP)

\section{$6^{\text {th }}$ May}

Fierce battles in Afghanistan have left about 64 rebels, nine Afghan soldiers and a policeman 
dead over that past three days, the US military said on Tuesday. (AP)

\section{$7^{\text {th }}$ May}

Three children were killed and one injured when a mine exploded in Qarabagh district of the southern Ghazni province. A local health official said on Saturday.

\section{8 $^{\text {th }}$ May}

At least two people were killed and five injured in a suicide bomb explosion in an upscale Kabul neighborhood Saturday evening.

\section{$9^{\text {th }}$ May}

The toll from a weekend bombing at an internet café in the Afghan capital Kabul rose Sunday to three dead including the suspected suicide bomber and six wounded, a spokesman for NATO led troops said. (AFP)

\section{$10^{\text {th }}$ May}

Two US Marines and up to 23 militants were killed in a clash in Afghanistan amid an upsurge in violence by Taliban fighters. (AFP)

\section{$12^{\text {th }}$ May}

Hundreds of students rampaged through an eastern Afghan city Wednesday to protest desecration of the Holy Quran by US military interrogators at Guantanamo Bay. Police opened fire to control the rioters, and four people were reported killed and 71 wounded. (AP)

\section{$13^{\text {th }}$ May}

At least three Afghans were killed and as many injured in the troubled southern Zabul province in a bombing attack blamed on Taliban insurgents. (PAN)

\section{$14^{\text {th }}$ May}

Anger spread in Afghanistan on Friday over a report that US interrogators as Guantanamo Bay had desecrated the holy Quran as nine more people were killed and about 30 wounded in protests, police and residents said.

\section{$15^{\text {th }} \mathrm{May}$}

Afghan and foreign forces were on high alert Saturday after 14 people died in violent protests over alleged desecration of the Quran by US interrogators at Guantanamo Bay. (PPI)

\section{$16^{\text {th }}$ May}

A group of Afghan Ulema has threatened to call for Jehad (Holy War) against the US if Washington fails to tum over in three days to a Muslim country interrogators reported to have desecrated the Holy Quran at its Guantanamo
Bay prison, VoA and Doordarshan reported on Sunday.

\section{$17^{\mathrm{th}} \mathrm{MaY}$}

Two Afghan soldiers were killed and five more injured when their vehicle ran over a landmine in southern Afghanistan, the US military said Monday, blaming insurgency for the attack.

(AFP)

\section{$18^{\text {th }}$ May}

Armed men kidnapped an Italian woman working for an international relief agency by pulling her from a car in the center of Kabul Monday; officials said an Italian news report said the woman worked for CARE International. (Agencies)

\section{$19^{\text {th }}$ May}

Danish aid organization Mission OEST's office in northeastern Afghanistan has been looted and jeeps were set on fire during violent anti- American demonstration. (NNI)

\section{0 $0^{\text {th }}$ May}

Suspected Taliban militants ambushed and killed six Afghans Thursday as they were transporting the body of government engineer killed a day earlier in another deadly rebel attack, officials said. (AP)

\section{$21^{n}$ May}

Gunmen shot and killed six Afghans in an ambush on a major highway in the country's troubled south Thursday, the second fatal attack in two days on employees of a USfunded anti-drugs project, officials said. (Agencies)

\section{$23^{\text {rd }}$ May}

Four people were killed on the spot and eight wounded on when a van carrying wedding guests hit in landmine in the southern Ghazni province. (Online)

\section{$24^{\text {th }}$ May}

One US soldier has been killed and three more were wounded in a bomb attack in the southern Afghan province of Zabul. (Online)

\section{$25^{\text {th }} \mathrm{May}$}

Afghan and coalition forces killed two insurgents in a firefight in central Afghanistan, while US aircraft bombed and destroyed a cave where about six other bodies were believed hiding, the US military said Tuesday. (AP)

\section{$27^{\text {th }}$ May}


An Afghan de-miner was killed while clearing old explosives at the airport in the country's capital, a UN spokesman said Thursday. (AP)

\section{$29^{\text {th }}$ May}

Twelve civilians were killed after unknown assailants opened fire on them in eastern Afghanistan's Kunar province Friday, provincial governor said Saturday. (AFP)

\section{$30^{\text {th }}$ May}

The Taliban have claimed responsibility for the assassination of prominent Kandahar cleric Mullah Abdullah Fayyaz and have warned other clergymen supporting Afghan president Hamid Karzai and the US that they would meet the same fate.

Eleven civilians were killed Saturday in a landmine explosion in Mangoi district of the eastern Kunar province, the Interior Ministry confirmed on Saturday.

\section{$31^{\text {st }}$ May}

Twelve civilians were killed after unknown assailants opened fire on them in eastern Afghanistan's Kunar province, the provincial governor said. In a separate incident, two soldiers were wounded in a grenade.

\section{Refugees}

\section{$I^{\text {at }}$ May}

The government of Pakistan and UNHCR has compiled and analyzed the finding of the first ever census of Afghan refugees in Pakistan, the survey team includes some 2,000 Pakistani employees.

\section{$4^{\text {th }}$ May}

Some 16,000 Afghan refugees have been so far repatriated to their homeland from Iran voluntarily a provincial official said. (INP)

\section{$6^{\text {th }}$ May}

Some 500 Afghans have been repatriated during the current year from Pakistan under the UN Refugee Agency program, a UNHCR official said on Thursday. (APP)

\section{$8^{\text {th }}$ May}

The ambassador for the UN refugee Agency Angelina Jolie on Saturday disagreed President General Parvez Musharaf's idea to relocate Afghan refugee camps out of Pakistan saying it is a wrong idea.

\section{$9^{\text {th }}$ MaY}

Director of Khorasan for foreign residence affair said there that over 7,286 Afghan refugees have returned home from Dogharoun Border checkpoint since the beginning of the current Iranian year. (INP)

\section{$10^{\text {th }}$ May}

Over 50,000 Afghan refugees have returned home from Pakistan since the resumption of UN assisted repatriation program in March.

(PPI)

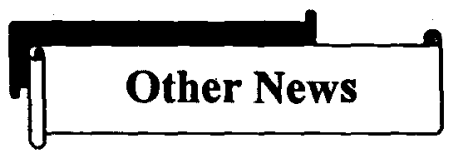

\section{$2^{\text {ed }}$ May}

Six people included four children have been missing for three days after heavy snowfall in Jurm district in the northeastern Badakhshan province. (NNI)

Based on a decree by president Hamid Karzai, and in accordance with article 20 of the law on mass media, a temporary commission for Afginan national radio and television broadcasting has been established. (NNI)

\section{$3^{\text {rd }}$ May}

UNICEF welcomed the adoption of a new Juvenile Code by Afghan government, declaring the new legislation a fundamental building block for the protection of Afghan children. (Online)

\section{$6^{\text {th }}$ May}

A team of Indian cardiologists started threeday free treatment of heart patients, examining around 300 people here. (NNI)

\section{$7^{\text {th }}$ May}

More than 300 women took to the streets of Kabul to protest growing violence against then and demand that the Karzai government take action against those responsible for the recent deaths of five women. (NNI)

\section{2th May}

Four people were killed and cropped land washed away by severe floods in the northern Takhar province during the last two days, officials says. (NNI)

\section{$10^{\text {th }}$ May}

Afghanistan's apex court vehemently denounced the reported desecration of the holy Quran by American investigators at their naval base in Guantanamo Bay in Cuba. (SANA)

\section{May}


Heavy rain falls over the last few days in the central and southwestern parts of Afghanistan, has led to extensive flooding of agriculture land leading to loss of life and the killing of hundreds of animals, aid bodies said. (SANA)

\section{$15^{\text {th }}$ May}

The United States should apologize for any desecration of the Muslim Holy book, the Quran and punish those responsible, a top Afghan official said on Saturday as sporadic anti US protests flared for a fifth day.

(Agencies)

\section{$17^{\text {tk } M a y}$}

President Hamid Karzai will be talking to US authorities during his visit to the United States at the end May, about the release of Afghan prisoners held at the US detention centers within Afghanistan and Guantanamo Bay camp in Cuba, the president's spokesman Jawed Ludin said. (NNI)

\section{$19^{\text {th }} \mathrm{May}$}

A group of Afghan Islamic clerics have deferred a call for holy war against the United States over a magazine report that US interrogators desecrated the holy Quran after the report was retracted. (Agencies)

\section{4.t May}

A diabetic center opened at Kabul's Maiwand Hospital as part of a bid to treat for free patients suffering from the disease. (SANA)

\section{$27^{\text {th }}$ May}

Afghan health workers battling polio will set off in to remote mountains next week hoping to reach about two million children who missed an immunization drive because they were cut off by heavy snow. (PPI)

\section{0" May}

The Afghan National Army, in conjunction with the office of military cooperation Afghanistan, initiated the program to improve the health of the soldiers and enhance mission readiness. (PPI)

\section{$31^{\text {st }}$ May}

Children injured by land mines will be among those to benefit from a new pediatric hospital built nun by Germans in Kabul. (NNI) 


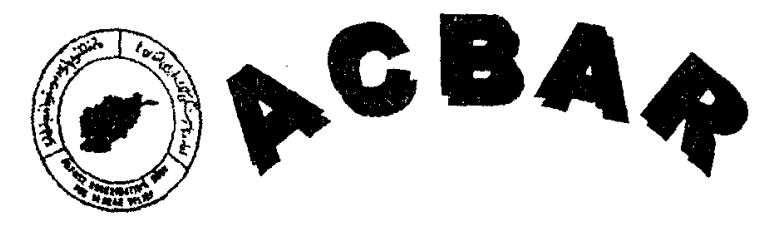

News Summary for June-2005

\section{Aid and Economic Development}

$2^{\text {nd }}$ June

SMEDA would provide expertise to the

Afghan traders and businessmen in the development of small and medium entities in Afghanistan. (APP)

Sarhad Chamber of Commerce and Industry and Afghanistan International Chamber of Commerce and Industry have agreed to form a joint commission for the promotion of bilateral trade between two neighboring countries.

(APP)

\section{$5^{\text {th }}$ June}

50 Iranian trade and service companies are currently active in Afghanistan. The corripanies are involved in production of potable water, medicine, polyethylene pipe, electrical switches etc... (NNI)

\section{$10^{\text {th }}$ June}

Cement prices in Afghan capital city have been on the rise following the closure of the underconstruction Mahipar Road linking Kabul with Torkham. (Online)

\section{$12^{\text {th }}$ June}

The Asian Development Bank (ADB) will grant $\$ 1.785$ million to conserve wildlife resources in the buffer zones through a technical assistance. (NNI)

\section{$17^{\text {th }}$ June}

Kazakhstan is ready to invest in the Afghan economy, Kazak's foreign minister said in at the international business conference in Almaty. (NNI)

The US President has announced military aid of \$161.5 million to Afghanistan for defense purchases and training. (Online)

\section{$19^{\text {th }}$ June}

Afghan President Hamid Karzaiand his Tajik counterpart Emamali Rahmanov Saturday jointly inaugurated construction work on the
Amu River (Oxus) bridge linking the neighboring countries. (PAN)

$20^{\text {th }}$ June

Extra funds for fighting the Afghan drug trade have been pledged by the most industrialized nations, the UK home secretary has said. (NNI)

\section{$21^{\text {tt June }}$}

Sayed Tayeb Jawad, ambassador of Afghanistan to the United States signed two major grant agreements totaling $\$ 85$ million with the international Development Association. (IDA) at World Bank. (NNI)

\section{$22^{\text {nd }}$ June}

A federation of the Afghan businesswomen will be established in a month with a start up fund from the United States Agency for International Development (USAID), an official said Sunday. (PAN)

The United Nations' food aid agency said it will provide 88 tones of food to the people in north-eastern areas of Badakhshan province that were hit by heavy flooding last week. (SANA)

\section{4th June}

The World Bank will consider a project to provide help to Afghanistan to reduce the drug production. (NNI)

\section{$25^{\text {th }}$ June}

Pakistan Red Crescent Society handed over a relief consignment worth Rs. 1.5 million to Afghan ambassador Dr Nangyalai Tarzi fro the needy and flood affectees of Jalal Abad. (Online)

Foreign Minister from the G8 group of leading industrialized nations has pledged support for Afghanistan beyond parliamentary elections in September. (Agencies)

\section{June}


World Bank has agreed to release a grant of $\$ 265$ million for uplift projects in Afghanistan during the current year. (PAN)

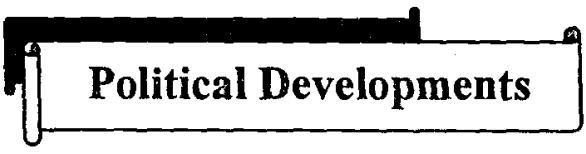

\section{$5^{\text {th }}$ June}

Afghan president Hamid Karzai returned from Washington with a strategic partnership with the United States neatly sewn up. It has committed successive US governments to stay for a long term in Afghanistan. (Online)

\section{$8^{\text {th }}$ June}

Afghanistan government and the UNAMA have initiated discussions regarding future cooperation between Afghanistan and the international community after holding in September of the parliamentary election, which will mark the formal completion of the Bonn process. (NNI)

\section{$9^{\text {th }}$ June}

President Hamid Karzai met British foreign minister Dr Kim Howells in his office. They discussed the aid programs provided by the British government, drug-enforcement program and ways of increasing the government's income. (NNI)

\section{$13^{\text {th }}$ June}

Afghanistan's President Hamid Karzai has authorized a ministerial task force obliged to eliminate violence against women, a UN spokesman said Thursday. (NNI)

President Hamid Karzai is scheduled to leave for neighboring Tajikistan on a daylong official visit on Monday to inaugurate construction work on a bridge on the Ammo River. (Online)

Afghanistan has rejected allegations regarding its involvement in the uprising in Uzbekistan, saying it was an internal affair of the neighboring country. (NNI)

Pakistan President General Parvez Musharaf Sunday telephoned his Afghan counterpart Hamis Karzai and discussed with him matters pertaining to mutual cooperation.

Interior minister Aftab Ahmad Khan Sherpao has termed his recent visit to Kabul, capital of Afghanistan, as very successful and fruitful. (NNI)

\section{$17^{\text {th }}$ June}

Al-Qaeda chief Osama-bin Laden and Taliban leader Mullah Mohd Omar are not in Afghanistan, the US ambassador said Thursday, a day after a top Taliban commander said the pair were alive and well. (AP)

\section{$18^{\text {th }}$ June}

Osama bin Laden's al-Qaeda network is regrouping and repairing to bring Iraq style bloodshed to Afghanistan, the defense ministry said Friday. (Agencies)

$19^{\text {th June }}$

Pakistan foreign office spokesman Saturday rejected as irresponsible a statement by former US envoy to Afghanistan, Zalmai Khalilzad, in which he claimed that Taliban leader Mullah Omer was in Pakistan. (APP/NNI)

\section{$23^{\text {rd }}$ June}

Latest accusations against Pakistan by the US Administration and Afghan government regarding presence of terrorists on its soil show the US finally became impatience in hunt of Osama Bin Laden. (PPI)

Pakistan may feel somewhat relieved over the increased engagement in Iraq of the outgoing aggressive US ambassador to Kabul, Zalmay Khlailzad.

Interior Minister of Pakistan has said that President Musharaf has lodged a strong protest with the US and Afghan leaders regarding the statement of Zalmay Khalilzad. (Online)

\section{$26^{\text {th June }}$}

The Afghan government has reshuffled the governors of four key provinces Kabul, Kandahar, Ghazni, and Nangarhar for administrative reasons, the Afghan Islamic Press reported. (NNI)

\section{$27^{\text {th }}$ June}

President Karzai here Sunday congratulated Mahmood Ahmedinejad over his victory in the June 24 run off the presideritial election, media reported. (INP)

\section{$28^{\text {th }}$ June}

Senior military officials from Pakistan, Afghanistan and the United States are meeting today (Tuesday) in Kabul under the tripartite commission formed to discuss border issues and review progress on war against Taliban hiding on soil.

Electoral News 


\section{$1^{\text {st June }}$}

A total of 6,085 Afghans have registered to stand in the historic 18 September legislature and provincial council elections.

\section{$2^{\text {nd }}$ June}

Canada contributed \$8 million to support Afghanistan's upcoming parliamentary and provincial elections. (NNI)

\section{$3^{\text {rd June }}$}

A JEBM statement issued said here the registration of voters, having been listed for the presidential ballot, would get under way from June $25^{\text {th }}$. Every Afghan citizen 18 years of age or above is eligible to vote in elections. (NNI)

\section{$6^{\text {th }}$ June}

The election commission Sunday announced July 1 Deadline for all the prospective candidates to disarm their private militias and armed bands before contesting for a seat.

\section{$12^{\text {th }}$ June}

Several candidates in the southern Ghazni province have withdrawn their candidature following complaints regarding their relationship with electoral office staffers. (NNI)

\section{$13^{\text {th }}$ June}

In the build up to the September polls, a fiveweek technical training course for 120 newly appointed administrative officers of the Parliament Secretariat began here on Saturday. (Online)

Afghanistan on Saturday launched a new drive to disarm militiamen ordering more than 1,000 illegal armed groups to hand over their guns as the country pressured for a parliamentary election.

\section{$16^{\text {th }}$ June}

The NATO led international peacekeeping force announced on Wednesday that 2,000 more troops would be deployed in different cities of Afghanistan to secure upcoming parliamentary polls.

\section{$19^{\text {th }}$ June}

Afghanistan's UN-backed electoral commission will launch a new voter registration drive next week for country's first post conflict parliamentary elections, the organization said Sunday. (AFP)

\section{$20^{\text {th }}$ June}

US forces in the southern Ghazni province have arrested candidate for the upcoming Afghan's parliamentary elections, officials said. (SANA)

The Swedish government has decided to send four election observers, three long terms and one short-term observer to Afghanistan for the parliamentary and provincial elections on 18 September. (NNI)

\section{$24^{\text {th }}$ June}

Names of 16 parliamentary election candidates have temporarily been removed from candidates list for allegedly possessing weapons UNAMA election officials said. (NNI)

\section{$27^{\text {th }}$ June}

About 255 former Jehadi commanders have so far voluntarily disarmed to join the upcoming parliamentary polls, JEBM spokesman said. (NNI)

\section{$28^{\text {th June }}$}

Kochis in the southern Ghazni province complained against what they called less number of polling stations allotted to them in the province. (NNI)

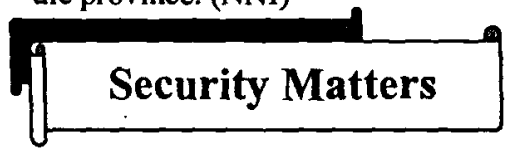

\section{June}

More than six Taliban were killed on Monday in a clash with coalition forces and the Afghan army in Barmal district of the southern Paktika province, a statement from the coalition said on Tuesday.

Suspected Taliban attacked police headquarters in unruly southern Afghanistan leaving four police officers and seven fighters dead in the ensuring gunfight, a senior official said Tuesday.

\section{$2^{\text {ad June }}$}

A suicide attack on the funeral of key anti-

Taliban cleric on Wednesday killed at least 20 people including one of Afghanistan's top policeman and wounded $\mathbf{4 2}$ in the southern city of Kandahar.

\section{$4^{\text {th }}$ June}

A bomb explosion in Bolan killed a former police official and injured his two men, an official said Friday. (PAN)

\section{$5^{\text {th June }}$}


Two people were reported dead and 150 others affected as whooping cough broke out in the Adraskan district of the western Heart Province. (NNI)

\section{$8^{\text {th }}$ June}

Suspected Taliban killed two Pakistani truck drivers supplying fuel to US troops in Afghanistan on Tuesday, police said. (Reuters)

Taliban Tuesday claimed killing a senior security official of Khak-I-Afghan district along with two guards in the troubled southern province overnight, but government officials denied the claim. (PAN)

\section{$9^{\text {th }}$ June}

Taliban have claimed killing of six US troops in Afghanistan by exploding a bomb at Jalalabad Torkham highway. (Online)

$10^{\text {th June }}$

One US soldier was killed and eight others were injured as they came under mortar attack in Afghanistan's southeast Paktia province Wednesday, a US army statement said. (NNI)

\section{$11^{\text {th June }}$}

One US soldier and seven-suspected Taliban were killed Friday after an ambush on a joint US-Afghan patrol near Lawara in southeastern Afghanistan, the US military said. (AFP)

\section{$12^{\text {th }}$ June}

At least 12 Afghan passengers were killed when a minibus and a US military vehicle were in collision Saturday in southern Afghanistan, officials said. (APP)

\section{$13^{\text {th }}$ June}

An Afghan army truck collided with a bus Saturday in southern Afghanistan, killing three villagers and wounding seven, the interior minister said. (Online)

\section{$14^{\text {th }}$ June}

At least six people perished and 19 suffered injuries when a truck fell into a ditch on the Kabul-Jalalabad Highway, eyewitnesses said on Monday. (PAN)

\section{$15^{\text {th June }}$}

Four US soldiers were wounded Monday when a suspected Taliban suicide bomber drove a car packed with explosive in to an American military convoy in southern Afghanistan, officials said. (AFP)

Afghan and US led coalition forces killed two suspected insurgents and captured 13 others in a firefight in southern Afghanistan, the US military said Tuesday. (AP)

\section{$16^{\text {th }}$ June}

Afghan authorities have detained a police chief for questioning over killing of five Medicines Sans Frontiers (MSF) aid workers one year ago, the government said Wednesday. (APP)

\section{$17^{\text {th }}$ June}

A policeman, a teacher and two boys were killed in the latest spate of violence to hit Afghanistan, officials said Thursday. (AP)

$18^{\text {th }}$ June

A tribal elder and kin of a central minister Haji Abdul Wahid was gunned down in the Maiwand district of Kandahar province. (NNI)

\section{$19^{\text {th }}$ June}

Taliban took hostage Mia Nashin district police chief, his deputy and 11 soldiers in an overnight ambush in the southern Kandahar province.

\section{$20^{\text {th }}$ June}

Six Afghan government employees including a strict chief were wounded as a mine blew in the troubled southem Helmand province Friday. (PPI)

United States warplanes killed $15-20$ suspected Taliban militants in southern Afghanistan in the latest attack, The US military said on Sunday. (AFP)

\section{$21^{\text {" June }}$}

Three Pakistani Nationals who plotted to assassinate outgoing US ambassador Zalmay Khalilzad, were arrested Sunday in the western Laghman province.

Twenty-one people including an Afghan district governor, two policemen and many militants died in new attacks linked to the warbattered country's ousted Taliban regime, officials said Monday. (APP)

\section{$22^{\text {Nd June }}$}

Some 32 suspected Taliban were killed Tuesday when Afghan troops backed by US warplanes launched an operation against militants in southern Kandahar province. (NNI)

Afghanistan urged Pakistan Tuesday to clamp down on militants allegedly hiding on its side of the border. (AFP/AP)

\section{$23^{\text {rd June }}$}


Afghan and US trops backed by warplanes blasted Taliban hideouts in southwestem Afghanistan for second day, killing scores of militants in the bloodiest fighting in months.

$24^{\text {th }}$ June

Afghan and US forces have killed 132 Taliban militants and surrounded four of the ousted regime's top commanders afer a three-day battle in the south of the country.

(AFP/Reuters)

\section{$25^{\text {th }}$ Jure}

Afghan and US forces surrounded an area in southwestern Afghanistan where Taliban's leader Mullah Onar could be hiding. (PPI) Taliban guerillas killed a candidate and two of his bodyguards in an ambush in the central province of Uruzgan, the provincial governor said. (PPI)

\section{$26^{\text {th }}$ June}

Afghan forces scouring mountains in the country's south have found the bodies of another 78 suspected fighters, bringing to 178 the insurgent death ioll. (AP)

\section{$27^{\text {th }}$ June}

Eight people inciuding two German scldiers and six Afghan workers were kifled and seven others wounded in an explosicn in the Rostaq district of the northern Takhar province.

\section{$28^{\text {th }}$ June}

US troops shot dead a suspected militant on motorcycle that spod up to a checkpoint in southern Afghanistan. (Reuters)

\section{$29^{\text {th }} \operatorname{June}$}

A grenade attack on the home of an Afghan refugee kiled two of his daughters injured his wife, son and another daughter in Jalozay Camp in Peshawar. (AP)

Bomb killed a top policeman and four other people in Afghanistan on Tuesday and rockets struck near a UN election office. (Reuters)

\section{$30^{\text {th }}$ Jure}

Unidentified rien have killed three policemen and wounded two others in Laghman province, VOA radio said. (INP)

President Hamid Karzai inatigurated a military compound costing $\$ 70$ millions in the southeastern city of Gardez. $2^{\text {nd }}$ June

The UN High Commissioner for Refugees (UNHCR) on Wednesday said the agency is looking to repatriate $400,000 \mathrm{Afghan}$ refugees during the current year.

\section{$3^{\text {rd }}$ June}

The UNHCR Thursday anounced the camps closure in Pakistan would not force refugees to leave the country. A dozen of refugee camps will be close down in North Waziristan Agency by the end of June.

\section{Sthe June}

Afghan Commissioner ate NWFP has decided to close down all schools for $A$ fghan refugees working in various camps under the supervision of Education Cell before June 30. (PPI)

\section{$7^{\text {th }}$ June}

The UN Refugee Agency will begin on Wednesday to register Afghans in North Waziristan who wish to repatriate from Pakistan because of the government decision to close all refugee camps in this troubled region along border with Afghanistan. (NNI)

\section{June}

A number of Afghans who are not only running established business in Pakistan but even have already got the National Identity Card are also contesting the schedule parliamentary elections in Afghanistan.

$10^{\text {th }}$ une

The office of the United Nations High Commissioner for Refugees (UNHCR) has launched a special drive to help repatriate Afghans living in refugee camps in the North. Waziristan Agency of Pakistan's western tribal belt. (NNI)

\section{$12^{\text {th }}$ June}

A new tripartite agreement between Iran, Afghanistan and the office of the United Nations High Commissioner for Refugees (UNHCR) has been signed in principle regarding repatriation of $A$ fghan refugees. (NNi)

\section{June}

A two-day seminar on Refugee Women and Children, The Courage to Survive "was held at a local hotel in Peshawar Wednesday. (APP)

\section{$18^{\text {th }}$ June}

The UN Refugee Agency has begun issuing repatriation documents to Afghans from North 
Waziristan on Wednesday following a registration process that showed 83 percent of the residents of refugee camps wish to return to Afghanistan. (Online)

The UN Refugee Agency announced it would end assistance in two troubled afghan camps in Balochistan Province, supporting a government decision to close them this summer and offer residents a choice of repatriation or relocation in another camp. (Online)

\section{$24^{\text {th }}$ June}

Dozens of houses in Azakhel refugees' camp have been damaged as the floodwater surged in to populated area. (Agencies)

\section{$26^{\text {th }}$ June}

Over 10 percent of the existing Afghan refugees in Karachi are set to voluntarily repatriate to Afghanistan by the end of 2005, according to the United Nations High Commission for Refugees.

\section{$27^{\text {th }}$ June}

About 15,000 Afghan refugees will return to their homeland till July 6. (PAN)

\section{$29^{\text {th }}$ June}

Minister Sardar Yar Muhammad Rind has said that more that four million Afghan refugees settled in Pakistan would be not allowed business after year 2006 in any part of the country including Sendh, (Online)

\section{Other News}

\section{$5^{\text {th }}$ June}

The government of Turkey is taking charge of training Afghan National Defense Ministry doctors. (NNI)

\section{Sth June $^{\text {th }}$}

Rain-induced floods washed away a village in Nasi locality of the northem Badakhshan province killing four people, official said on Sunday. (PAN)

\section{$11^{\text {tk }}$ June}

An Italian aid worker freed after three weeks as a hostage in Afghanistan left for home Friday, even as security forces continued to hunt for her kidnappers, official said. (AP)

\section{$14^{\text {th June }}$}

Archeologists have discovered an ancient town in the Nirk district of the central Wardak province. (Online) $15^{\text {th June }}$

The Public Health Ministry Department, in collaboration with an NGO called Health Net, launched an AIDS awareness campaign in the astern Nangarhar province on Monday. (SANA)

Three people were killed after flooding washed away three villagers in central Bamyan province, officials said on Tuesday.

$16^{\text {th }}$ June

A five members boxing team is scheduled to leave for Pakistan to participate in an Asian boxing event to be held in the port city of Karachi. (PAN)

\section{$17^{\text {th }}$ June}

The only center for rehabilitation of drug addicts in Heart city was closed down for luck of funds, leaving 23 patients under treatment in a quandary. (NNI)

\section{$18^{\text {th }}$ June}

Sever flooding caused by storms and torrential rains in parts of Afghanistan left up to 48 people dead and washed away more than 1,000 homes, a minister said Friday. (AFP)

\section{$20^{\text {tk June }}$}

Afghan authorities are rushing to chlorinate hundreds of drinking water wells across Kabul amid fears that the city could $b$ eon the verge of a cholera epidemic. (NNI)

$21^{\text {st June }}$

Despite of preventing measures taken by government, diarrhea, which has so far claimed five lives, is spreading in Kabul City, health ministry said on Sunday. (PAN)

\section{3rd June}

Sacked health staffers of the UNHCR and Afghan Commissionarate continued their hunger strike even after lapse of one month, as there was no government official to give any assurance to the aggrieved.

\section{$24^{\text {th }}$ June}

Floods have played havoc with human life and property in parts of Nangarhar, Laghman and Takhar provinces. (NNI)

\section{$28^{\text {th }}$ June}

The recent overflow in Kabul and Kunar rivers have damaged 281 houses and inundated thousands acres of cultivated land destroying crops in the eastern Nangarhar province. (NNI) 


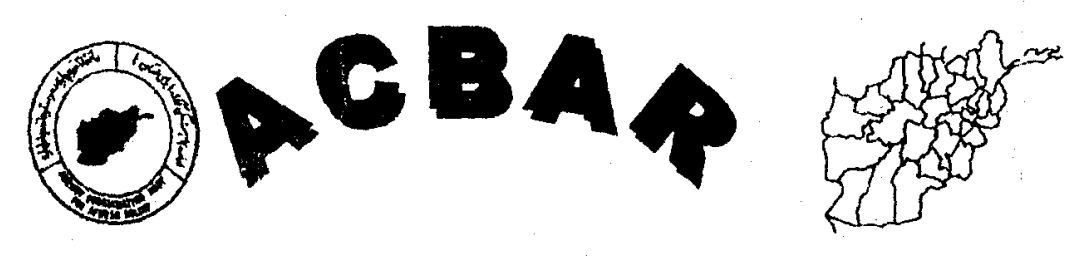

News Summary for July-2005

\section{Aid and Economic Development}

$1^{\text {st July }}$

The ministry of Rural Rehabilitation and Development will complete thousands of small reconstruction projects across the country under the National Solidarity Program. (PAN)

\section{$2^{\text {nd July }}$}

United Nations (WFP) is delivering emergency aid to the people stricken by heavy floods. (NNI)

\section{$6^{\text {th }}$ July}

Rural Rehabilitation and Development Minister Mohammad Hanif Atmar Tuesday announced 10 million Afghanis in aid for flood hit areas in the northeastern Badakhshan province. (PAN)

\section{9th July}

Japan will give Afghanistan 3.75 billion Yen in grant to help improve infrastructure, build new schools and buy vaccines for infants. (NNI)

\section{$10^{\text {th July }}$}

Afghanistan has proposed to Pakistan an agreement on fruit exports via air-conditioned containers. (PAN)

\section{$13^{\text {th }}$ July}

ADB has approved a US\$55 million grant to help rehabilitate Afghanistan's primary road network damaged during two decades of conflict and neglect. (APP)

\section{$15^{\text {th }}$ July}

Health Minster Dr. Amin Fatimi has said 214 Basic Health Units (BHUs) will be operative in different parts of the capital in the next two months. (PAN)

\section{$16^{\text {tt }}$ July}

Gold trade in the western Harat province has reduced by $50 \%$ in the wake of crack down on drug smuggling to Iran. (INP) $17^{\text {th July }}$

A Dubai based adventure tour company plans to take adventurous holidaymakers from the Gulf to Afghanistan to aid in reconstruction of the country. (Agencies)

\section{$18^{\text {th }}$ July}

Minister for mines and minerals Mir Muhammad Siddiq Sunday suggested increase in the ratio of taxes on imported goods to improve the country's tattering economy.

\section{0"th July}

The road, linking provincial capital with the Harat Kandahar Highway, is being constructed with\$30 million assistance from the United States. (Online)

\section{$22^{\text {*a July }}$}

Unicef, in collaboration with the provincial education department, is planning to open 100 makeshift primary schools in the central Bamiyan province. (NNI)

\section{$23^{\text {rt }} \mathrm{July}$}

Pakistan will ask the Karzai-led administration to impose zero rating duty on its exportable products in response to Afghanistan's demand for reducing items from the negative list under Afghan Transit Trade (ATT) agreement.

\section{4. $4^{\text {th }}$ July}

The United Kingdom has pledged \$350 million in aid for reconstruction in the war-ravaged Afghanistan. (SANA)

\section{$25^{\text {th July }}$}

Pakistan and Afghanistan signed an investment protection treaty, as Islamabad announced a grant of $\$ 100$ million for Kabul as a gesture of goodwill and friendship between the neighbors. (PAN)

\section{$27^{\text {th }} \mathrm{July}$}

Pakistan has provided 42 truckloads of food items worth Rs. 25 million to Afghan authorities in Quetta. (PAN) 
$28^{\text {th }}$ July

Afghanistan has been the single largest recipient of Canadian bilateral aid with pledges of more than $\$ 616$ million in reconstruction and development assistance. (NNI)

\section{$29^{\text {th }} \mathrm{July}$}

The 300 telephone booths established by the communication ministry at different spots in the capital would start functioning. (NNI)

\section{Political Developments}

\section{$1^{\text {st July }}$}

Interior minister Ali Jalali will continue to stay on his position.

\section{$6^{\text {th }}$ July}

Osama Bin Laden and Mullah Omar are not in Afghanistan, according to Afghanistan's foreign Minister Dr. Abdullah. (Online)

$19^{\text {th }}$ July

British Prime Minister Tony Blair will host talks with President Hamid Karzai on Tuesday 12 days after the London bombings. (AFP)

\section{$20^{\text {th }}$ July}

Pakistan Prime Minister Shaukat Aziz will pay an official visit to Afghanistan on July $24^{\text {th }}$ for talks with Afghan President Hamid Karzai. (Online)

\section{$21^{\text {st }}$ July}

An Afghan envoy Wednesday repudiated NWFP Chief Minister Akram Khan Duranni's accusation that Afghanistan was meddling in Pakistan's internal affairs. (PAN)

\section{$22^{\text {nd }}$ July}

France remains committed to help Afghanistan in its transition process, as part of a broader European defense policy to stem international terrorism, French Defense Minister Michele Alliot-Marie wrote Thursday in the Wall Street Journal. (AFP)

\section{$23^{\text {rd July }}$}

Afghan President Hamid Karzai was due to hold talks with Italian Premier Silvio Berlusconi Friday during the second day of a visit to Italy. (AP)

\section{$24^{\text {th }}$ July}

Prime minister Shaukat Aziz will visit Kabul amid growing Afghan irritation over Taliban infiltration across its southern border. (Agencies) $25^{\text {th }}$ July

Afghan President Hamid Karzai believes progress in the Middle East peace process and Palestinian statehood augur possible diplomatic relations between Israel and Afghanistan. (AP)

\section{$31^{\text {st }}$ July}

US President George W. Bush has discussed on phone with Afghan President Hamid Karzai about the coming legislative elections in Afghanistan. (INP)

\section{Electoral News}

\section{$2^{\text {nd }}$ July}

Sixteen percent of candidates for the upcoming parliamentary elections are gunmen or affiliated with armed groups, Afghanistan's Independent Human Rights Commission Alleged. (NNI)

\section{$3^{\text {rd }}$ July}

Kochi voters and candidates alike say the small number of seats allotted to them in the new legislature represents just the latest action in a long history of government oppression. (NNI)

\section{$4^{\text {th }}$ July}

The ECC of the JEMB has temporarily dropped the names of 233 parliamentary and provincial council nominees. (SANA)

\section{$6^{\text {th }}$ July}

The JEBM has begun the education campaign using a network of 1,600 advisors who will reach potential voters through schools, universities, mosque and other public places. (SANA)

\section{$7^{\text {th }}$ July}

The United Nations Said Wednesday that parliamentary and provincial election can be held throughout Afghanistan in September despite difficult security environment. (Online)

\section{$14^{\text {th }}$ Julv}

The UN sponsored Joint Electoral Management Body has confirmed over 5,000 aspirant candidates to contest the first parliamentary election in the post-war Afghanistan. (NNI)

\section{$16^{\text {th }}$ July}

Candidates and residents of the eastern Nangarhar province have asked the government to extend dateline for registration 
as a large number of people are yet to get listed. (NNI)

\section{0 $0^{\text {th }}$ July}

Afghanistan's election body has finally approved a list of 5,805 candidates to stand in parliamentary and provincial elections on September 18. (NNI)

Japan has announced $\mathbf{\$ 8}$ million in assistance for the keenly awaited Afghan parliamentary elections. (NNI)

$28^{\text {tk }}$ July

Upon the invitation of Afghanistan, the European Union has established an election observation mission to Afghanistan to observe the parliamentary election on September 18 . (NNI)

The UN sponsored (JEBM) is preparing 40 million ballot papers for Afghans in the coming first post Taliban parliamentary election. (NNI)

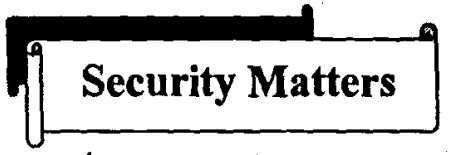

$1^{\text {st July }}$

The governor of the insurgency plagued southern Uruzgan province said that he narrowly escaped an assassination attempt. (NNI)

\section{$2^{\text {nd }}$ July}

President Hamid Karzai inaugurated military compound costing $\$ 70$ millions in the southeastern city of Gardez. (Online)

\section{$3^{\text {rd July }}$}

Team of soldiers missing after fierce fighting that included the shooting down of a Special Forces helicopter with 16 soldiers abroad earlier this week. (Online)

US planes have bombed a suspected Taliban hideout the same area of eastern Afghanistan where US servicemen are missing, reportedly killing 25.

\section{$4^{\text {th }}$ July}

India and Afghanistan today discussed the security situation in the war-ravaged country. (Agencies)

\section{$5^{\text {th }}$ July}

Four Afghan journalists covering an ongoing US-led operation in eastern Afghanistan have been detained by local security agencies. (AFP) $6^{\text {th }}$ July

Three Afghan journalists, arrested by intelligence officials in the eastern Kunar province at the weekend, were shifted to Kabul. (NNI)

\section{$7^{\text {th }}$ July}

Two Special Forces soldiers missing for several days in the rugged mountains of eastern Afghanistan were found dead, but one member of the team remained unaccounted for. (Online)

\section{8th July}

Two suspected Taliban militants were killed and three others captured after they ambushed a police check-post in southern Afghanistan.

\section{(AFP)}

\section{$10^{\text {tk July }}$}

Taliban claimed on Saturday they had executed a US commando captured late last month, but the US military expressed unawareness about the navy official's killing.

NATO's top military officer met with Karzai at the presidential palace. The discussion touched on NATO's expansion within the country, Afghanistan's security and other aspects.

\section{$11^{\text {th July }}$}

The US military on Saturday set free from the Bagram airbase another 76 Afghans held on suspicion of having links with the Taliban movement. (NNI)

\section{$12^{\text {t* July }}$}

Four suspected militants escaped from a heavily fortified jail at the main American base in Afghanistan on Monday. (APP)

Taliban claimed on Monday they had killed a dozen Afghan army soldiers in the troubled provinces of Kandahar and Zabul. (PAN)

\section{$14^{\text {th July }}$}

Seventeen Taliban fighters were killed and six captured in fierce fighting in the troubled southern province of Zabul.

\section{July}

Two bombs exploded in quick succession at an election commission office in restive southeastern Afghanistan, injuring two policemen. (AFP)

The United States, Pakistan and Afghanistan need to improve their cooperation to crush 
suspected Taliban and Al-Qaeda fighters staging raids in Afghan territory. (Agencies)

Twenty-four suspected Taliban fighters were killed in a missile attacked by US planes near the Pak-Afghan border in North Waziristan Agency the Pakistan army troops have recovered bodies of the killed persons.

\section{$17^{\text {th }}$ July}

The US military Saturday released another batch of 20 Afghan prisoners from its main detention center where four Al-Qaeda linked Arab militants escaped last week. (AFP)

$18^{\text {th }} \mathrm{July}$

Afghan army And US-led forces killed 20 Taliban southeast of the country. (Reuters)

$19^{\text {th }} \mathrm{July}$

A tribal leader and ally of President Hamid Karzai has been kidnapped and hanged by the Taliban as violence in Afghanistan continues to intensify in the approach to elections planned for September. (Agencies)

\section{$20^{\text {th }}$ July}

A district governor escaped unhurt Tuesday when targeted in western Afghanistan. The incident happened in the Injil district of Harat province. (APP)

\section{$21^{\text {tt }}$ July}

The Afghan police have thwarted a rocket attack against a major hydropower dam near Kabul the latest threat to stability in Afghanistan ahead of parliamentary elections. (Online)

\section{2 $2^{\text {nd }}$ July}

Fighting across Afghanistan left 14 people dead, including nine tribesmen killed by suspected Taliban. (AP)

\section{July}

Kidnappers have abducted three Afghan electoral workers in an area of eastern Afghanistan where a female colleague was wounded in an attack days earlier. (AFP)

\section{6 th $^{\text {th }}$ uly}

An Afghan electoral worker educating voters on upcoming parliamentary elections was shot dead in southeastern Afghanistan. (AFP)

$27^{\text {th }}$ July

Parliamentary candidate Dr Ezatullah from southeastern Paktika province was killed in a bomb attack on Monday. (PAN) $28^{\text {th }}$ July

Three suspected Taliban fighters were killed and two wounded in a gun fight which aiso left five policemen injured in southern Afghanistan. (AFP)

$29^{\text {th }}$ July

A fire that broke out as it made a hard landing with six-coalition crew and 25 Afghan troops on board destroyed a US-led coalition helicopter. (AP)

\section{$31^{\text {t }}$ July}

Four US servicemen and an Afghan interpreter were wounded in two different incidents as officials claimed killing 10 Taliban and capturing 15 others in southern parts of Afghanistan.

Parliamentary candidate engineer Fidai killed along with his six bodyguards in Gizab district of Uruzgan. (INP)

\section{Refugees}

$1^{\text {st July }}$

The government of Iran has agreed to allow Afghan refugees to stay in the Gulf country for another year. (Online)

\section{$4^{\text {th }}$ July}

The Pakistani government wants to close down several more Afghan refugee camps in South Waziristan Agency, in the NWFP and Balochistan. (PAN)

\section{$6^{\text {th }}$ July}

Former Chairman Human Rights of Pakistan Afrasyab Khattak has alleged that Pakistan was forcibly expelling Afghan Refugees. (PPI)

\section{9th July}

Two hundred and thirty Afghan families went back to their homes from Pakistan. (AP)

\section{$14^{\text {th }}$ July}

The United Nations, apparently contradicting the statement of a Pakistani minister, has ruled out the repatriation of all refugees by the end of the current year. (PAN)

\section{$24^{\text {th July }}$}

Afghans living in a refugee camp scheduled for closure by August, have asked Pakistani authorities to extend the life of the facility for at least one year, to give residents a chance to make proper arrangements to leave. (SANA)

\section{$26^{\text {th July }}$}


More than 2.5 million Afghans have repatriated from Pakistan as the UN refugee agency's largest voluntary repatriation program continues to assist refugees to return to Afghanistan. (Online)

\section{$28^{\text {th }}$ July}

Afghan refugees will face legal action if they do not return home voluntarily by the end of current year. (APP)

\section{1" July}

Under a UNHCR sponsored repatriation plan, 22 Afghan refugee families left Punjab province for their homeland. (PAN)

\section{Other News}

\section{$1^{\text {st July }}$}

Flood killed six people and destroyed dozens of homes in mountains in eastern Afghanistan.

\section{$6^{\text {th }}$ July}

The Health Department of Baghlan province of Afghanistan has said that about 750 women and children die daily due to lack of medicines and hospitals in Afghanistan. (APP)

\section{$8^{\text {th }}$ July}

The Afghan badminton team will leave for Jakarta Thursday to take part in an international tournament scheduled to get under way net week. (Online)

\section{$11^{\text {th }}$ July}

A new independent cultural and intellectual organization was founded in Ghazni province, writers, intellectuals and journalists from other provinces attended the opening ceremony. (NNI)

\section{$13^{\text {th }}$ July}

A large gold mine, also containing precious stones, has been discovered in the western province of Harat. (NNI)

\section{$20^{\text {th }} \mathrm{July}$}

Provincial officials Monday set ablaze 11 metric tones drugs in the Dash Hawz area of Harat province. (PAN)

\section{$23^{\text {rd July }}$}

Japanese researchers say they have found ancient murals in a cave near Afghanistan's giant Buddha statues that were destroyed by the Taliban. (SANA)

\section{$28^{\text {th }}$ July}

France and Britain sent home a plane hold of Afghan nationals as part of new European crackdown on illegal immigration, the French Interior Ministry said.

\section{$31^{\text {st }}$ July}

The United Nations backed special counter narcotics Criminal Justice Task Force (CJTF), created to fast track major drug cases within Afghanistan. (NNI) 


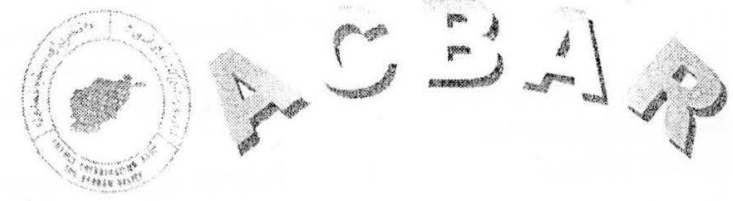

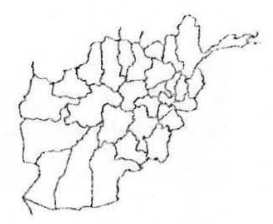

News Summary for August-2005

\section{Aid and Economic Development}

$1^{\mathrm{st}}$ August

The 20 percent tax levied on registered companies will prove a crushing blow for the country's nascent economy. (PAN)

The Afghanistan-Korea Vocational Training Center opened in a ceremony in the Afghan capital of Kabul, the Korea International Cooperation Agency said. (NNI

\section{$4^{\text {th }}$ August}

The Asian Development Bank and the Afghan government signed a $\$ 50$ million agreement on developing an efficient power distribution system in Afghanistan. (Online)

\section{$5^{\text {th }}$ August}

Afghan farmers have returned to cotton cultivation, sowing the crop over 6,000 hectares of land in the northern Kunduz province after decades of sirife. (PAN)

\section{$8^{\text {ih }}$ August}

The Japanese government has given US\$ 2 million to support the UN Refugee Agency operations in Pakistan. The contribution was received at the agency's head quarter office in Geneva.

Pakistan is going to expand the Afghan transit trade list by adding three more items to boost trade ties between the two neighbors. (PAN)

\section{$10^{\text {th }}$ August}

Afghanistan expects to eam $\$ 1.8$ million annually in taxes on use of its airports and air space under a new law approved last week by the Karzai cabinet.

Hamid Karzai has called for further improving relations with Pakistan so that the economic ties between the two countries can be given a boost.

Afghanistan expects to earn $\$ 1.8$ million annually in taxes on use of its airports and air space under a new law approved by the Karzai Cabinet.

The World Bank has provided $\$ 25$ million of interest-free loan to the government for bringing improvements in the basic urban services in the most vulnerable areas of the capital.

\section{$14^{\text {th }}$ August}

The Asian Development Bank Friday said that it has approved a technical assistance grant of 1 million doliars to help Aighanistan's air transport system by boosting management of the country's civil aviation administration.

\section{$17^{\text {th }}$ August}

State-run Power Grid Corporation today entered into an agreement with Ministry of External Affairs of India for executing $\$ 110$ million transmission project in Afghanistan.

\section{$20^{6 \mathrm{~h}}$ August}

Pledging all possible cooperation in the reconstruction of Afghanistan. China has suggested a trilateral trade agreement among Kabul, Beijing and Dushanbe on transit of goods. (PAN)

\section{$21^{\text {st }}$ Aupust}

The Federal Government of Australia will give A fighanistan can extra $\$ 7$ million to help with its reconstruction and next month's elections. (NNI)

\section{$22^{\text {nd }}$ August}

The Finance Ministry agreed to consider a possibility of the full write-off of $70 \%$ of Afghanistan's debts and significantly reduce the debt on economic loans restructuring the debt remainder on easy terms. (NNI)

\section{$24^{\text {th }}$ August}

New Zealand will contribute 1 million NZ dollars (700,000 US dollars) to the United Nations to assist in the running of elections in Afghanistan on September 18. (NNI) 


\section{$26^{\text {th }}$ August}

The (PRT) stationed in the Parwan Province. launched four construction projects in the neighboring Kapisa Province. (PAN)

\section{$28^{\text {th }}$ August}

To get a strong footing and minimize Pakistan's influence in Afghanistan, India is expected to offer an aid of USD 50 million for Afghanistan. (INP)

The Afghan government in collaboration with the United Nation Office for Project Services (UNOPS) will soon launch reconstruction of 260-kilometer roads leading to villages in seven provinces. (PAN)

\section{$30^{\text {th }}$ August}

The World Bank will give the Afghan government $\$ 135$ million in aid to tackle problems the landlocked country faces in harsh wintry condition. (PAN)

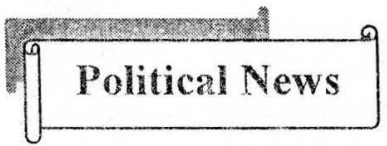

\section{$2^{\text {nd }}$ Augast}

Prime Minister Manmohan Singh is expected to visit Kabul in August to lay the foundation stone for the new Afghanistan parliamentary building. (Agencies)

The Defense Ministry said Thursday Afghanistan was at an advanced stage of preparations for taking control of Afghan prisoners being held in various US detention facilities. (PAN)

\section{$19^{\text {th }}$ August}

- Pakistani leaders have greeted President Hamid Karzai on Afghanistan's Independence Day falling on August 19. (NNI)

\section{$22^{\text {nd }}$ August}

Afghan President Hamid Karzai Sunday defended a recent agreement on strategic partnership with the US, saying his conflictcrippled country could not progress without support from the international community.

\section{$23^{\text {rd }}$ August}

Afghanistan's foreign minister said his strifetorn country needs a long-term commitment from the international community to support its development and to strengthen peace in the region. (AP)
Pakistani, Afghan and US officials would gather in Islamabad to consider Pak-Afghan border security. (Onlinc)

Afghan President Hamid Karzai called upon the countrymen to move towards self-reliance and stand on their feet in rebuilding the war shattered country. (NNI)

\section{$25^{\text {th }}$ August}

Indian Prime Minister Manmohan Singh will pay a two-day official visit to Afghanistan to hold official level-talks with President Hamid Karzai. (APP)

\section{$26^{\text {th }}$ August}

The arrival in Kabul of Afghanistan's former defense minister General (Rtrd) Shah Nawaz Tanai, has fueled anti-Pakistan and anticommunism sentiment in section of the Afghan capital's political and media circles.

\section{$27^{\text {th }}$ August}

India said that its efforts to help rebuild Afghanistan are being hampered by Pakistan, which lies between the two countries and refuses to allow Indian aid to be shipped through its territory. (AP)

\section{$28^{\text {th }}$ August}

Moscow's call for the repayment of $\$ 10$ billion debt by Kabul has drawn ire from Afghan officials and analysts, who in turn asked Russia to pay their country's war reparations. (PAN)

\section{$29^{\text {th }}$ August}

Indian Prime Minister Manmohan Singh who arrived to Kabul on his two-day trip, held talks with President Hamid Karzai on bilateral, regional and international issues.

\section{$30^{\text {th }}$ August}

Visiting Indian Prime Minister Manmohan Singh voiced his country's willingness to help Afghanistan stamp out terrorism, saying a menace posed a serious threat to all societies.

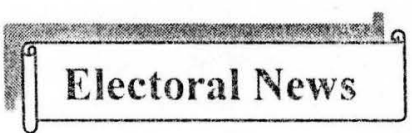

\section{$5^{\text {th }}$ August}

A delegation of European Union has arrived in Kabul to monitor forth coming Afghan parliamentary elections being held on $18^{\text {th }}$ September this year. ( $\mathrm{PP})$

\section{$5^{\text {th }}$ Auguist}

\section{$24^{\text {th }}$ August}


A delegation of European Union has arrived in Kabul to monitor forth coming Afghan parliamentary elections being held on $18^{\text {th }}$ September this year. (APP)

\section{$9^{\text {th }}$ August}

Afghanistan still faces a funding shortfall of 19 million dollars for next month's key parliamentary elections, but the polls will go ahead as planned. (AFP)

\section{$10^{\text {th }}$ August}

The United States has pledged an additional $\$ 8$ million to supplement $\$ 32$ million in US funds already provided to authorities administrating the landmark parliamentary elections in Afghanistan. (Online)

\section{$12^{\text {th }}$ August}

Transportation of ballot papers and other pollrelated materials to polling stations across Afghanistan has been launched, announced the JEMB

\section{$14^{\text {th }}$ August}

The afghan electoral body has started transporting ballot materials throughout the country for the forthcoming parliamentary elections scheduled for 18 Sepiember.

\section{$17^{\text {th }}$ August}

The one-month formal campaign of the candidates for the upcoming Afghan parliamentary elections begins, said JEMB. (NNI)

\section{$20^{\text {th }}$ August}

Afghan President Hamid Karzai urged his countrymen on Friday to vote for candidates who were honest and would uphold the law in the war-torn country's parliamentary elections * next month. (AFP)

\section{$24^{\text {th }}$ August}

American and Afghan commanders have prepared detailed security plans for the September national elections there that call for local forces to provide two inner rings of protection at 6,000 polling stations while foreign troops stand by, out of sight, a s reinforcement in case of serious attacks. (NNI)

\section{$25^{\text {th }}$ August}

The JEMB announced they were striving to ensure full fledges transparency during the polls. (PAN)

\section{$30^{\text {th }}$ August}

Several female constants for the upcoming legislative parliamentary elections and provincial council elections complained they were facing host of problems in carrying out their election drive. (SANA)

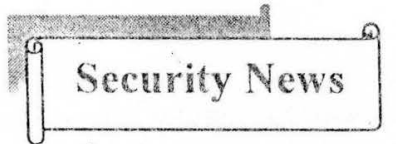

\section{$1^{\text {st }}$ August}

President Hamid Karzai welcomed a decision by Australia to send 150 elite troops to Afghanistan by September to fight a growing tide of insurgent-led violence by remnants of the Taliban and Al-Qaeda.

\section{$2^{\text {nd }}$ August}

Alghan security forces have seized thousands of missiles mortar rounds and artillery shells in their biggest weapons haul in months. The ammunitions cache was found in the Khogyanai district of central Ghazni province. (NNI)

Germany said it had no indications that its use of an airport in Uzbekistan to supply its forces in Afghanistan would be affected by a decision on stop US using a base in the country. (Reuters)

\section{$3^{\text {rd }}$ Augus}

Unidentified gunmen have kidnapped two workers of an NGO called Coordination of Humanitarian Assistance in the western Farah Province. (PAN)

\section{$4^{\text {ih }}$ August}

llamid Karzai had a meeting with Gen Etham Erdagi the outgoing commander in chief of International Security Assistance Force (ISAF) in Kabul. (NNI)

Aghan insurgents have killed four government troops and four police oflicers in an attack on a checkpoint in the country's east. (AFP)

\section{$5^{\text {th }}$ August}

Italy on Thursday took command of the NATO led peacekeeping force in Afghanistan for a nine month period which will see an expansion of security for next month's historic parliamentary polls. (AFP)

\section{$6^{\text {th }}$ August}

The US Embassy have announced on Thursday Washington would soon start transferring Afghan detainees to the Karzai ledgovernment, which has assured it can take care of the prisoners.

\section{$7^{\text {th }}$ August}


$\Lambda t$ least six people including a woman were killed in an armed clash between two families in the southern Helmand Province. (PAN)

\section{$8^{\text {th }}$ August}

A candidate in next month's parliamentary election has escaped unharmed after an attcmpt on his life in northern Afghanistan. (AFI)

\section{$9^{\text {th }}$ August}

A NATO led international force will be expanded and ready to assume responsibility for security across all over Afghanistan by the end of next year. (PPI)

\section{$10^{\text {th }}$ August}

One US soldier and at least 16 militants died when insurgents attacked a patrol of Afghan and US troops in the latest clash to rock Afghanistan ahead of key clections. (AFP)

\section{$11^{\text {th }}$ A ugust}

At least four civilians were killed and six others wounded as the US-led Coalition forces" jets pounded an area in the Dai Chopan district of the southern Zabul Province.

\section{$13^{\text {th }}$ August}

In one of the rare cases of its kind. Taliban executed a woman Wednesday after accusing her of spying for the US and afghan militaries in the restive southwestern Zabul Province.

\section{$16^{\text {th }}$ August}

Defense Ministry Monday claimed killing 21 Taliban following a crackdown in Zabul and Uruzgan provinces.

\section{$17^{\text {th }}$ August}

Suspected Taliban abducted a Lebanesc engineer in the southern Zabul province. (Online)

\section{$19^{\text {th }}$ August}

Canada took over from the US the command of a local civil-military reconstruction team (PRT) in the southern province of Kandahar. (NNI)

\section{$20^{\text {th }}$ August}

Armed men in the western Harat stabbed a senior official of the JEMB after ransacking his house. (NNI)

\section{$21^{\text {st }}$ August}

At least 20 people were killed and 28 others injured when two buses collided on a highway in southern Afghanistan. (AFP)

\section{$22^{\text {nd }}$ August}

Four US soldiers were killed and three wounded in an improvised explosive device attack in southern Afghanistan while two American oflicials received injuries when an embassy convoy came under bomb attack in Kabul. (AFP/AP)

\section{$23^{\text {rd }}$ August}

Taliban fighters will not attack polling stations during next month's election in $\Lambda$ fghanistan. a spokesman for the guerrillas said, but he vowed that the war against the government and US forces would go on. (Reuters)

\section{$24^{\text {th }}$ August}

A US military base near the capital city came under missile attack, which caused no damage. (NNI)

\section{$25^{\text {th }}$ August}

The US-led Coalition and $\Lambda$ fghan soldiers in Zabul Province killed six Taliban fighters in a joint operation. (PAN)

\section{$26^{\text {th }}$ August}

US and $A$ fghan troops backed by helicopter gunship and warplanes killed five-suspected Taliban, the military said bringing to 16 the number of rebels who have reportedly died in two days of clashes. (AFP)

\section{$27^{\text {th }}$ August}

On $31^{\text {st }}$ August the NATO-led International Security Assistance Forces will complete the deployment of additional forces in support of the National Assembly and Provinciz.l Council Elections in Afghanistan. (PPI)

\section{$28^{\text {th }}$ August}

Eight people were killed and six otters injured following ahead on collision betwee $\mathrm{n}$ a speedy truck and a passenger coach. (PAN)

\section{$29^{\text {th }}$ August}

Another candidate was gunned down in restive Uruzgan Province on Saturday mounting the toll to four since the beginning of the electoral fray in the war ravaged country. (PAN)

\section{$30^{\text {th }}$ August}

NATO-led peacekecpers have deployed 2,000 extra troops across northern and western $\Lambda$ fghanistan to secure the war-battered country's parliamentary elections on September 18. (AFP)

\section{$31^{\text {st }}$ August}

NATO's top commander began a two day visit to Afghanistan to prepare for a planned cxpansion of the alliance's peacekecping 
mission and assess moves to beef up the firec ahead of next month's election. (Agencies)

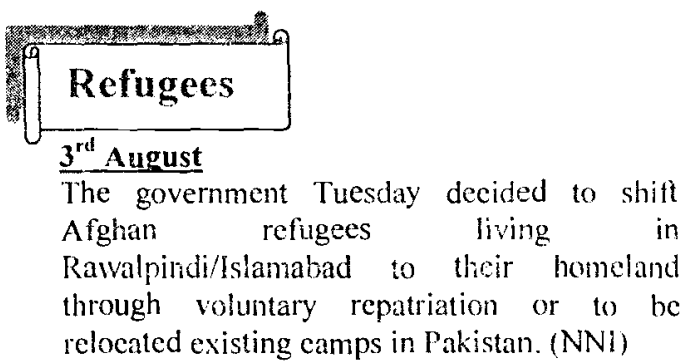

Around 1.000 people gathered at Kabul stadium and critioged the ministry of Refugec Affairs for payng no attention to their problems. (NNI)

\section{$4^{\text {th }}$ August}

Pakistan Wednesday rejected Afghanistan's request not to repatriate Afghan religees and forcign students at various seminaries of the couniry.

Afghan refugees residing in the twin cities of Rawalpindi and Islamabad will be repatriated. (APP)

\section{$5^{\text {th }}$ August}

Aighan refugees having bogus doeuments are illegal and they would be treated according to law. (APP)

The UNHCR has so far helped repatriating mose than 2.5 million Afghan refugees fiom Pakistan under the voluntary repatriation program launched in 2002. (APP)

\section{$7^{\text {th }}$ Angust}

The Pakistani government informed Alghans in the Pederally $A$ dministered Tribal Areas - bordering Afghanistan that all remaining refugee camps in Bajawur and Kuram Agencies home to over 105.000 refugees would be closed on Auglist 31 . (Online)

Spokesman of the UNHCR has said that 1.2 million Afghan refugees have so far been repatriated from Iran to their country. (APP)

\section{$9^{\text {th }}$ August}

Thousands of Afghan nationals stationed at refugee camps in Islamabad and two tribal agencies will be asked to repatriate before September 1.

\section{$10^{\text {th }}$ August}

Afghanistan has described the expulsion of refugees from the twin cities of Rawalpindi and Islamabad as Pakistan's unilateral decision, saying they had not been consulted on the issue. $(P \wedge N)$

\section{$12^{\text {th }}$ August 2005}

Thousands of $A$ fghan refugees are defying orders to leave camps in Pakistan's tribal region, which are being closed because of security

\section{$14^{\text {th }}$ August}

Thousands of $\Lambda$ fghan refugees in Islamabad and Rawalpindi refused to comply with September 15 deadines for repatriation to their homeland.

\section{$16^{\text {th }}$ August}

The $A$ fghan refugees in Kurram $\wedge$ gency refugees' camp have started repatriating to their homeland.

\section{$22^{\text {nit }}$ August}

The UN refugee agency assisted 183 returning families with building materials for construction of houses in Orgun district of the southeastern Paktika province. $(P \wedge N)$

\section{$23^{\text {rit }}$ August}

Afghanistan called on Pakistan to postpone the closure of all refugee camps in the Pakistani tribal regions. ( $\triangle \mathrm{FP}$ )

\section{$24^{\text {th }}$ August}

A three partite ineeting of $A$ fghanistan. Pakistan and the UNHCR would be held in Kabul to revicw the repatriation process of Atghan refugees that has gained pace from their camps established in Kurram and Bajawur Agency. (APP)

\section{$25^{\text {it! }}$ august}

The UNHCR launched its Census Report of Afghan refugees in Pakistan, which reveals that nearly $82 \%$ Pashtun population lives in all the four provinces of Pakistan.

\section{$27^{\text {th }}$ August}

Sut of 21,500 Aghan families, 7.500 have been repatriated under the auspices of INHCR from Kurram Agency where as the camps vacated by the refugees are being demolished by the oncerned authorities.

\section{$29^{\text {th Angust }}$}

The Conmissioner Afghan Refugees Sahibrada Ances has said August 31 would complete the repatriation process from Kurram Agency.

\section{$31^{\text {st }}$ August}


The Governments of Afghanistan, Pakistan and the UN Refugees Agency have agreed to extend the Tripartite Agreement, which regulates the repatriation of Afghans. (Agencies)

\section{Other News}

The UNESCO plans to introduce a literacy program for women aged between $15-45$ in southern city Kandahar. (PAN)

\section{$4^{\text {th }}$ Angust}

At least 7 major reproductive health care centers have been reactivated in hospitals of Kabul after the United Nations Population Fund (UNFPA) made funding available. (APP)

\section{$\underline{5}^{\text {th }}$ August}

A cholera epidemic has broken out in New Bahar district of the southern Zabul province. with officials warning of large-scale deaths if medicines do not reach the victims in time. (NNI)

\section{$12^{\text {th }}$ August}

The Tolo Television, a private TV channel in Afghanistan, has expanded its transmissions to Kandahar City.

\section{$13^{\text {th }}$ August}

Afghanistan's famous Bamiyan Buddhas are due to be recreated by multicolored laser images projected onto the cliffs where they once stood.

\section{$21^{\text {st }}$ August}

A huge Stupa dating the sixth century AD and another small stupa. which supposed to be from the third century, have been discovered in the Bamiyan province. (NNI)

\section{$26^{\text {th }}$ August}

University students in the central Bamiyan Province have staged a demonstration to protest against the loss of teaching staff at Bamiyan University. (NNI)

\section{$30^{\text {th }}$ August}

As many as 700 doctors from different medical centers of 14 provinces would be trained to cure mental patients by using modern medical techniques. (NNI) 


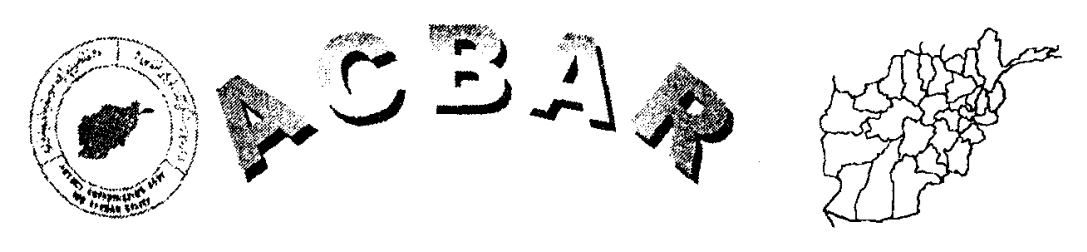

News Summary for September -2005

\section{Aid and Economic Development}

\section{$4^{\text {th }}$ September}

Nineteen thousand tons of melons have been exported to India via Pakistan from the southern Afghan province of Kandahar. (Online)

\section{$5^{\text {th }}$ September}

The Afghan government has embarked on countrywide distribution of chemical fertilizers and improved seeds to farmers a $\$ 25$ million initiative funded by the USAID and Britain. (PAN)

\section{$14^{\text {tht }}$ September}

Twenty tones of grapes were exported this week from the southern Afghan city to India and the United Arab Emirates. (Online)

\section{$16^{\text {th }}$ September}

Canada plans to award Afghanistan with $\$ 4.2$ million to hold Afghan parliamentary election scheduled for Sunday. (PPI)

\section{$18^{\text {th }}$ September}

Asia Pulse Afghanistan's telecom sector is set to attract a record US\$80.2 million investment for two companies, Invest come Consortium and Watan Mobile, who emerged as the successful bidders. (NNI)

\section{$20^{\text {th }}$ September}

Pakistan has exported goods worth Rs 115 million to Afghanistan over the last two months. (PAN)

\section{$26^{\text {th }}$ September}

The Afghan government has extended the facility of digital telephones to the western Ghor Province. (PAN)

\section{$28^{\text {th }}$ September}

Afghanistan's government rejected the recommendation that it legalize its massive opium crop, which supplies most of the world's heroin, and turn it to the production of medicine. (AFP)

\section{$30^{\text {th }}$ September}

Contributed supports for Afghanistan reconstruction is the focus of a $\$ 484,020$ US

Trade and Development Agency (USTADA) grant awarded to Kabul University for development of a training program on internationally standardized accounting practices. (NNI)

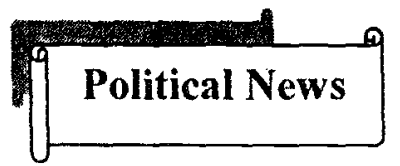

\footnotetext{
$6^{\text {th }}$ September

Two provincial governors have been replaced in northern Afghanistan after a spate of demonstration against one of them. (NNI)
}

\section{$7^{\text {th }}$ September}

Pakistan rejects a claim by an Afghan governor that the two Japanese nationals whose bodies found in Spin Boidak of Kandahar were killed on the other side of the border. (NNI)

\section{$9^{\text {th }}$ September}

The head of Afghanistan's opposition said President Hamid Karzai was a weak leader and a new parliament, to be elected on September 18 , would have to improve government policy across the board. (Reuters)

\section{$12^{\text {th }}$ September}

Taliban were not involved in 9/11 attacks and the united States of America made is a pretsxt to invade Afghanistan, Taliban Supreme Council (AIP)

\section{$13^{\text {th }}$ September}

Former Taliban Ambassador in Islamabad Abdul Salaam Zaeef has been released from the infamous Guantanamo. 
$13^{\text {th }}$ September

Afghan President Hamid Karzai urged the international community to rethink its antiterror strategy in the country. (AFP)

\section{5th September}

Analysts and political leaders in Pakistan rejected the fencing of Pak-Afghan border saying the step would create rifts between Pakhtuns living on both sides of the Durand Line. (PAN)

\section{$18^{\text {th }}$ September}

US President George W. Bush Thursday rung up President Hanid Karzai and thanked for Afghanistan's assistance for the hurricane Katrina. (NNI).

\section{$20^{\text {th }}$ September}

World leaders including America, Britain, Australia, EU and UN security General Kofi Anan praised the Afghanistan elections.

\section{$28^{\text {th }}$ September}

Interior Minister Ali Ahnad Jalali who has expressed frustration over the alleged involvement of officials in Afghanistan's burgeoning drug trade, said Tuesday he is resigning to his academic career. (AFP)

\section{$29^{\text {th }}$ September}

Afghainistan once again poured scorn on Pakistan's idea of fencing the Durand line, saying the border had been imposed on the Afghan nation, which would decide its late. (Online)

\section{Electoral News}

\section{$1^{\text {st }}$ September}

- The European Commission has pledged to provide 9 million Euros to finance the budget for the September 18 polls, which faces a funding shortfa!l.

The JEMB has accredited around 2200 independent observers and more than 30,000 political party and candidates to scrutinize the 2005 Wolesi Jirga and Provincial Council election.

\section{$4^{\text {th }}$ September}

Hundreds of fake voter registration cards have been seized in southern provinces of Kandahar and Zabul, a local election commission official said. (PAN)

\section{$8^{\text {ith }}$ September}

The JEMB said that 21 candidates for the forth-coming legislative elections have been banned to run for election. (Online)

\section{$9^{\text {th }}$ September}

Japan will give Afghanistan an additional $\$ 5$ million to help the country hold elections 18 September for a national assembly and provincial assembly and provincial councils. $(\mathrm{NNI})$

\section{$10^{\text {th }}$ September}

The JEMB announced that 239 polling officers had been trained in the southern Kandahar to manage the upcoming parliamentary polls in that Province. (NNI)

European Union has allocated 9 million Euros for holding of afghan polls. (APP)

\section{$15^{\text {th }}$ September}

Organizers of Afghanistan's elections said they were confident extensive preparations to ensure the transparency and integrity of Sunday's voting would produce a result everyone could trust. (Reuters)

\section{$17^{\text {th }}$ September}

Afghanistan's landmark election campaign officially ended Friday. (AFP)

\section{ath Seprember}

Early estimates showed a turnout of just over 50 percent in Afghanistan's first parliamentary polls in more than three decades, below that of last year's presidential vote. The election chief said Monday. (AFP)

\section{$21^{3 t}$ September}

Afghanistan Tuesday began counting votes cast in the weekend's landmark parliamentary elections. (AFP)

\section{$22^{\text {nd }}$ Sentemiber}

Women made up 41 percent of the six million Afghans who voted in landmark legislative elections at the weekend, around the same as in last year's presidential poll. (AFP)

A number of candidates complained against banning their representatives to observe vote counting at the Kandahar regional center. (PAN)

\section{$25^{\text {th }}$ September}

Following allegations of rigging from a number of candidates, election officials quarantined several ballot boxes received from 
different polling stations in the southern Province.

\section{$27^{\text {th }}$ September}

A former Taliban stalwart and candidate for the Wolisi Jirga Mullah Abdul Salam Rocketi is leading the vote in the southern Zabul Province. (NNI)

\section{Security News}

\section{$1^{\text {st }}$ September}

A US aircraft bombed a Taliban position in central Afghanistan killing eight militants in the latest violence in the run-up to September 18 election. (Reuters)

\section{$\underline{3}^{\text {rd }}$ September}

Taliban fighters kidnapped five persons including an election candidate and district incharge. (AIP)

\section{$4^{\text {th }}$ September}

A former Taliban minister was among 15 commanders who pledged support to the government in Paktia Province. (PAN)

Nineteen Taliban rebels were killed in the troubled provinces of Uruzgan and Zabul, the Defense Ministry claimed. (PAN)

\section{$5^{\text {thl }}$ September}

A candidate in Afghanistan's September 18 elections was killed on Sunday when he stepped on a landmine outside his home. (Reuters)

\section{$6^{\text {1"l September }}$}

Thirteen Taliban combatants have been killed in fighting with US and Afghan forces in a southern province, and more than 40 other suspected militants have been arrested. (AP)

\section{$7^{\text {th }}$ September}

Afghan and US led Coalition Forces have killed 12 suspected militants in raids on their hideouts in southern Afghanistan. (AP)

\section{$9^{\text {th }}$ September}

Taliban claimed to have blown up an American military tank by remote control landmine leaving four American troops dead in Zabul. (AIP)

\section{$11^{\text {th }}$ September}

Gunman opened fire on a vehicle belonging to Afghan Defense Minister Abdul Rahim Wardak.

\section{$12^{\text {th }}$ Sentember}

The Defense Ministry of Afghanistan has completed deployment of troops in the provinces to secure the landmark parliamentary election to be held on September 18. (AIP)

\section{$15^{\text {th }}$ September}

Taliban militant shot dead seven civilians after finding a registration document for the weekend's milestone elections in their car. (AFP)

NATO chiefs tried to overeome disagreements over the alliance's future in $\Lambda$ fghanistan. including plans for it to take operations from the US Led Coalition there. (Reuters)

\section{$16^{\text {th }}$ Sentember}

Three Taliban fighters have been killed and one captured alive in a fresh anti-insurgency operation in the southern Uruzgan Province. (PAN)

\section{$17^{\text {th }}$ September}

Suspected Taliban militants shot dead a candidate in Afghanistan's weekend elections. as the guerillas warned voters they could be hurt unless they boycotted the polls. (Reuters)

\section{$18^{\text {th }}$ September}

Afghan forces claimed killing seven Taliban in the Shahr-I-Safa district of the southern 7.abul Province overnight. (PAN)

\section{$19^{\text {th }}$ September}

Two policemen and four suspected Taliban rebels were killed in clashes hours before key afghan elections Sunday, while a UN worker was injured by a rocket strike. (APP)

\section{$20^{\text {th }}$ September}

A vehicle carrying ballot boxes hit a landmine in the Garbavee village of the Khogyanai district in Nangarhar Province. (NNI)

\section{1"September}

Seven people were killed Tuesday in two separate ambushes in southern Afghanistan in the wake of parliamentary polls. (AFP)

President Hamid Karzai called for US-led troops to scale back operations. including air strikes and house searches, saying Afghanistan's military could take a bigger security role. (AFP) 


\section{$22^{\text {nd }}$ September}

The Taliban vowed on Wednesday to step up their holy war against foreign troops in Afghanistan and dismissed legislative polls held at the weekend as an American drama rejected by the Afghan people. (PPI)

\section{$24^{\text {th }}$ September}

Seven members of a singer group were shot dead on the border of Jozjan and Balkh Province. (AIP)

\section{$25^{\text {th }}$ September}

Unknown attackers fired four rockets on a rural suburb of the afghan capital Kabul but there were no casualties. (AFP)

\section{$26^{\text {th }}$ Sentember}

Five inmates were killed in a US military helicopter crash in the southern Zabul Province Sunday morning.

\section{$\underline{28^{\text {th }} \text { September }}$}

Human skulls, bones and worn out clothes signifying mass graves have been found in a dry ditch in Sra Qila areas, 10 kilometers of Paktika Provincial capital Sharan. (PAN)

\section{$29^{\text {th }}$ September}

A suicide bomber riding a motorcycle blew himself up outside an army-training center in the Afghan capital on Wednesday, killing 9 people and injuring 29.

\section{$30^{\text {th }}$ September}

5 people including an Afghan soldier were killed and 17 more were wounded in two separate accidents in Khost and Paktia Provinces. (PAN)

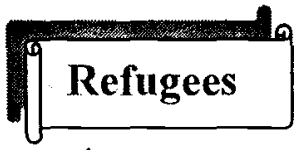

\section{$1^{\text {st }}$ September}

The governments of Afghanistan, Pakistan and the UN refugee agency have agreed to extend the Tripartite Agreemen.

\section{$3^{\text {rd }}$ September}

The number of Afghans who have returned to Afghanistan from refugee camps in Pakistan's Federally Administered Tribal Areas (FATA) has risen to 46,339 . A total of 103,070 individuals have registered with UNHCR to repatriate. (NNI)

\section{$9^{\text {th }}$ September}

At least 2070 families of Afghans have returned to Kunar Province via Nawa Pass from Afghanistan. (AIP)

\section{$19^{\text {th }}$ September}

Hundreds of Afghan families, ousted from refugee Kachi Abadi from Islamabad were tortured and baton charged by security personnel and shifted to unknown places from Jalozai camp Saturday.

\section{$24^{\text {th }}$ September}

The number of $A$ fghan exiles returning home from neighboring Pakistan and Iran since the fall of the Taliban has topped j4.2 million. The UN refugee agency said. (APP)

\section{Other News \\ $3^{\text {rd }}$ Sentember}

Some 4000 vaccinators and monitors will fan out across Afghanistan next week in a threeday United Nations supported campaign to immunize 7 million children under the age of five against polio. (PPI)

\section{$7^{\text {th }}$ Sentember}

A tuberculosis epidemic has left 12 people dead in a remote district of the westem Harat Province.

\section{$11^{\text {th }}$ September}

During a heavy rain and hailstone. a fierce flood washed away areas of the Spin Ghar and its slopes. Four persons were killed and 10 others injured in the Pacherogaham District of Nangarhar Province. (NNI)

\section{$15^{\text {th }}$ September}

Al-Qaeda Chief Osama Bin Laden is ill and seeking medical care. according to a US military commander in Afghanistan quoted by an Arabic newspaper. (AFP)

\section{$24^{\text {th }}$ Sentember}

Massive increases in drug production have been recorded in regions of A fghanistan where NATO in operating, just as the country counts votes from its first parliamentary elections. (PPI)

At least fourteen children and a woman reportedly died as a famine is spreading in remote villages in the Zebak district of the northeastern Badakhshan Province. (PAN) 


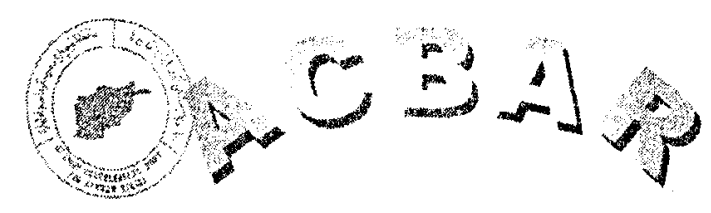

News Summary for October-2005

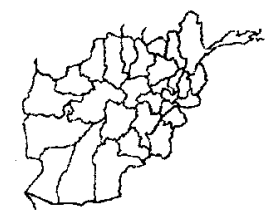

\section{Aid and Economic Development}

\section{$2^{\text {nd }}$ Octoljer}

China will back political peace and economic reconstruction process in Afghanistan, said

Chinese State Councilor. (SANA)

\section{$3^{\text {rd }}$ October}

Pakistan government will build Allama lqbal Arts Faculty in Kabul University and a hospital named Jinnah Hospital. (PPI)

\section{$4^{\text {th }}$ October}

Two thousand containers of transit trade goods of Afghanistan are stranded at Karachi port due to unavailability of adequate train facility. (PAN)

\section{$10^{\text {th }}$ October}

KEC International Ltd has said it has bagged two new others worth US\$36 million from ihe Ministry for Energy and water to the Alghan government. (NNI)

\section{$12^{\text {th }}$ October}

The third conference of (ECO) would be held in Kabul next month. (PAN)

\section{$18^{\text {th }}$ October}

Afghanistan's food and agriculture department plans to set up a juice and jam-manufacturing factory in collaboration with the Provincial Reconstruction Team (PRT) in the southern province of Ghazni. (SANA)

\section{$19^{\text {th }}$ October}

The Afghanistan International Chamber of Commence (AICC) Monday signed an agreement with Japan and Malaysia for exporting 7,500 tons of pomegranates. (Agencies)

\section{$26^{\text {th }}$ October}

The Afghanistan Investment Support Agency has registered more than 1,400 private investment companies during the current year. (NNI)

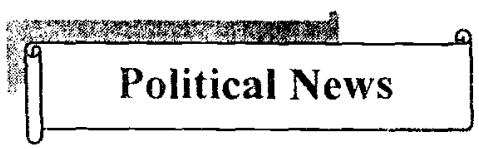

\section{$1^{\text {st }}$ October}

British Defense Secretary John Ried arrived Friday morning in Kabul for talks with Afghan President Hamid Karzai and Defense Minister Abdul Rahim Wardak. (PAN

Alghan President Hamid Karzai is scheduled to head to France on Sunday on a four-day visit as part of his campaign to muster foreign support for Afghanistan. (PAN)

\section{$6^{\text {th }}$ October}

Senior Taliban officials Wednesday confirmed their spokesman Hakimi's arrest by Pakistan: sccurity forces. saying his capture would not weaken the novement in any significant way. (PAN)

\section{$17^{\text {th }}$ October}

Alghan President Hamid Karzai would recognize Israel just after an independent Palestinian state is established. (Agencies)

\section{$20^{\text {th }}$ October}

President Hamid Karzai has invited Norsuitan Nazarbayev president of Kazakhstan to vis.it Afghanistan in 2006. (INP)

\section{$25^{\text {th }}$ October}

Afghan President Hamid Karzai met President Pervez Musharaf on Monday and condoled over the loss of precious lives in October 8 deadly earthquake. (Online)

\section{$27^{\text {th }}$ October}

Pakistan has announced the appointment of Tariq Aziz Uddin as Ambassador of l'akistan to the Islamic republic of $A$ fghanistan.

(Online) 
$28^{\text {th }}$ October

Afghanistan is set to join the South Asian Association for Regional Cooperition (SAARC) bouquet. (SANA)

\section{$29^{\text {th }}$ October}

The Shanghai Cooperation Organization and Afghanistan may create in the nearest future a contract group in order to cooperate witl each other. (NNI)

\section{$30^{\text {th }}$ October}

Four Afghan cabinet ministers have given up their foreign citizenship in the face of possible opposition from the future parliament.

(Reuters)

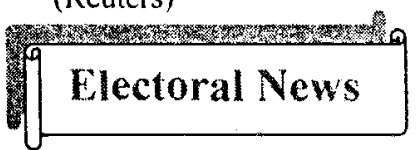

\section{$1^{\text {st }}$ October}

European Union raised concerns Friday over vote fraud in Afghanistan and called on the authorities to take measures to stop it. (AFP)

\section{$3^{\text {rd }}$ October}

Afghanistan's Election Commission vowed strong action against vote fraud on Sunday after international observers highlighted worrying cases of cheating in last month's landmark legislative elections. (Reuters)

\section{$5^{\text {th }}$ October}

Vote counting in Afghanistan's tirst parliamentary elections in more that $30 y$ cars was nearing completion Tuesday an ofticial said with warlords a former Taliban commander and women activist are among the front-runners to win the seats. (AP)

\section{- $9^{\text {th }}$ October}

More than a hundred candidates and around 500 of their supporters sceking a recount of votes in the northern city of Kunduz. (SANA)

\section{$11^{\text {th }}$ October}

Four election workers including the head of the joint UN Afghan poll panel's regional office in this Paktika capital city have been sacked on charges of fraud in vote count. (Online)

\section{$13^{\text {th }}$ October}

The JEMB Wednesday announced unofficial results from Logar, Wardak, Laghman and Panjsher provinces. (PAN)

\section{$15^{\text {th }}$ October}

Hundreds of losing candidates for the Afghan. parliamentary elections termed the polls as unfair and called for recounting herc. (NNI)

\section{$17^{\text {th }}$ October}

A UN backed Election Commission has dismissed about 50 of its staff for suspected fraud in last month's legislative elections. (PPI)

\section{$19^{\text {th }}$ October}

Former anti-Soviet Mujahiddin commanders, or Islanic warlords apparently dominate the first parliament in the post war Afghanistan as several dozens of them have been emerged victorious in the polls provisional results have indicated. (NNI)

\section{$24^{\text {th }}$ October}

President Hamid Karzai has rejected candidates' allegation that the government has interfered in the elections. (NNI)

Election organizers said Sunday the expect to finalize the results of landmark legislative polls by the end of the month. (AP)

\section{$27^{\text {th }}$ October}

JEMB has announced that the entire provincial results from the country's 18 September legislative elections have been published and certitied by the electoral commission. (NNI)

\section{$28^{\text {th }}$ October}

A top political opposition figure in Afghanistan on Thursday demanded a recisunt of last month's legislative elections and clained the legitimacy of the polis had been marred by widespread frand.

\section{$31^{\text {st }}$ October}

Final results from Afghanistan's parliamentary clections in September 18 are being delayed because of complaints of fraud. (Agencies)

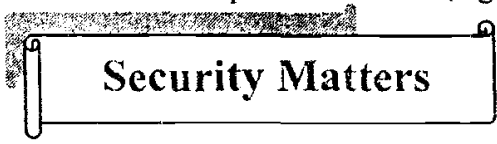

\section{$1^{\text {st }}$ October}

Five people including an Afghan National Army soldier were killed and 17 others sustained injuries in two separate traffic accidents in Khost and Paktia provinces. (NNI)

\section{$3^{\text {rd }}$ October}

As many as 11 people have died in four separate road accidents in different provinces of Afghanistan over the last 24 hours. (PPI)

\section{$4^{\text {th }}$ October}

US troops in Afghanistan and NATO -led ISAF forces will eventually work for one command under NATO, Afghan President 
Hamid Karzai said in a Newspaper interview. (Agencies)

\section{$5^{\text {th }}$ October}

At least six people including two A fighan soldiers were killed while 14 others received injuries in a powerful bomb explosion inside Afghanistan at Pak-Afghan border, some $90 \mathrm{~km}$ north of Quetta.

\section{$6^{\text {th }}$ October}

A suicide bomber blew himself up in his pickup truck and killed a child while missing the target of Canadian troops. (PAN)

\section{$8^{\text {th }}$ October}

President Hamid Karzai and the chief diplomat of NATO Thursday expressed optimism that the alliance could iron out problems over its planned expansion next year into the volatile south of country.

\section{$10^{\text {th }}$ October}

Six government officials were killed and five others sustained injuries in a traffic accident in the remote Nooristan Province. (Online)

\section{$11^{\text {th }}$ October}

A bomb exploded Monday at the clinic of a doctor standing for a seat in Afghanistan's first parliament in decades, wounded at least 13 people though the candidate escaped unhurt. (AFP)

\section{$12^{\text {th }}$ October}

As many as 20 policemen, including provincial security chief and three militants have been killed in an overnight clash in the restive Helmand Province. (NNI)

\section{$13^{\text {th }}$ October}

At least 10 Taliban combatants were killed as US fighter jets pounded suspected militant positions in the southern Uruzgan Province.

\section{$15^{\text {th }}$ October}

Eight fuel tankers were destroyed in an explosion outside a base for US-led coalition and Afghan forces in southern Afghanistan. (Agencies)

\section{$16^{\text {th }}$ October}

A pro-government religious leader and 15 others were killed when a bomb went off in a mosque in the eastern Afghan Province of Khost. (Online)

\section{$17^{\text {th }}$ October}

Taliban guerillas killed three Afghan men for spying for US troops. (INP)

\section{$18^{\text {th }}$ October}

Taliban militants gunned down a member of a provincial religious council and two security officers in separate attacks in insurgency hit southern Afghanistan. (AFP)

\section{$19^{\text {th }}$ October}

In a separate attack in Helmand Taliban fighters attacked a group of security officers killing an intelligence officer and a policeman ivhile other police officers suffered injuries. (Online)

\section{$20^{\text {th }}$ October}

Suspected Taliban insurgents shot dead a district chief in a mosque in Afghanistan's troubled south, a governor said Wednesday, in the forth killing linked to religion in less than a week. (AFP)

\section{$21^{\text {st }}$ October}

Unknown gunmen kidnapped and killed a school principle and janitor in separate attacks in insurgency hit southern Afghanistan. (AFP)

\section{$22^{\text {nd }}$ October}

President Hamid Karzai condemned the alleged desecration of Taliban bodies by US troops but he said mistakes happen in war and $\wedge$ fghans shouldn't let it mar their impression of the United States. (Agencies)

\section{$26^{\text {th }}$ October}

Millitants attacked security forces on two sides of Kabul killing seven people in some of the deadliest assaults near the Afghan capital in Months. (AP)

\section{$27^{\text {th }}$ October}

Fourteen Taliban prisoners were extradited from Pakistan to Afghanistan overnight, including two leaders of the hard-line militia removed from government four years ago. (Agencies)

\section{$28^{\text {th }}$ October}

A bomb fixed on a bicycle exploded in Kandahar on Thursday, killing a policeman and wounding two civilians. (AFP)

\section{$30^{\text {th }}$ October}

Taliban fighters have killed a man who contested Afghanistan's provincial elections last month. (APP)

\section{$31^{\text {st }}$ October}

Three US and four Afghan soldiers killed when their convey was ambushed by Taliban in east of Afghanistan. (Online) 


\section{Refugees}

\section{$1^{\text {st }}$ October}

The number of Afghans repatriating from Pakistan has passed the 2.7 million mark as the UN Refugee Agency's largest voluntary repatriation program in the world continues to assist refugees to return Afghanistan. (AIP)

\section{$6^{\text {th }}$ October}

Sajid Hussain Chattha, secretary Safron, who is leading Pakistan delegation to the $56^{\text {th }}$ session of the Executive Committee of the UNHCR in Geneva, called on Antonio Guterres, UN high commissioner for refugees and held meeting with the Afghan minister for refugees and repatriation and leaders of the delegation of the UK and Japan. (APP)

\section{$10^{\text {th }}$ October}

One million and 300,0000 Afghan refugees have been repatriated to their homeland in the past three years. (NNi)

\section{$14^{\text {th }}$ October}

Returnees to Afghanistan from both Pakistan and Iran will only get land for shelters in their province of origin, the government announced in the Afghan capital Kabul. (NNI)

\section{$21^{\text {st }}$ October}

Senior Advisor to UNHCR in Geneva said that 50,000 refugees have returned to their homeland from Iran through UN sponsored support programs since the beginning of the current Iranian year. (Online)

\section{- $29^{\text {th }}$ October}

The Japanese government has donated US $\$$ 1.5 million to the office of the United Nations High Commissioner for Refugees (UNHCR) in Iran to heip Afghan refugees. (NN:)

\section{Other News}

\section{$2^{\text {in }}$ October}

Millions of Afghan currency notes were disappeared from loaded trucks near Afghan border on Saturday, which were printed in France and being shifted to Kabul from Karachi. (INP)

\section{$7^{\text {th }}$ October}

Afghan custom officials in Kabul airport held three Nigerians after seizing more than 28 pounds of heroin believed headed for Europe. (PPI)

\section{$8^{\text {ith }}$ October}

A ten-member team of Kashmiris asylum seekers n Afghanistan held a peaceful demonstration here to mark their rights. (NNI)

\section{$11^{\text {th }}$ October}

A two-day seminar started here would find solution to the problems faced by the prisoners in country jails. (PAN)

\section{$16^{\text {th }}$ October}

Tents, plastic sheeting and other aid was piled Saturday into $40 \mathrm{UN}$ trucks in Afghanistan to be hauled in to neighboring Pakistan where those made homeless by the earthquake. (AP)

\section{$20^{\text {th }}$ October}

Afghanistan's independent Tolo TV arranged a program to discuss the role of the media in educating and informing the public and commented on the expansion of the Afghan media scene following the fall of the Taliban. (NNI)

\section{$24^{\text {th }}$ October}

An earthquake destroyed homes and killed five people near Afghanistan's eastern border with Pakistan on Sunday. (AP)

\section{$30^{\text {th }}$ October}

The US has invited three UN human rights investigators to visit the Guantanamo Bay prison camp in a bid to show there is nothing to hide. (Agencies) 


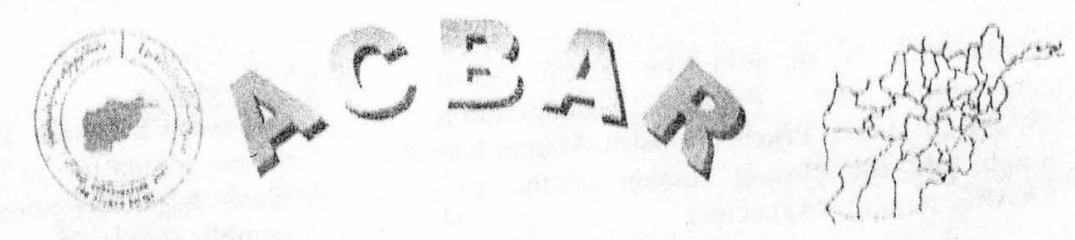

News Summary fors November-2005

Bue to whding up ACBAR Office in fleshotwar, the monthly news summary will not be published there on.

\section{Aid and Ficonomic Developanem}

\section{$8^{\text {th }}$ November}

Balkh Governor Atta Mohd Noor and the commander of the German forces in the north of Afghanistan have signed an agreement worth $50 \mathrm{~m}$ Euros for the building of Mazar-eSharif Airport. (NNI)

\section{$9^{\text {th }}$ November}

Afghanistan has joined the Central Asian Regional Economic Cooperation (CAREC) program, following a decision by the CAREC $4^{\text {th }}$ ministerial conference in Bishkik, Kyrgyz Republic. (NNI)

\section{$10^{\text {th }}$ November}

President Karzai will open the third business and investment conference of Economic cooperation organization (ECO) in which participants will decide on the use of the US\$5.4 million donated by this organization for the reconstruction of Afghanistan. (Online)

\section{$18^{\text {th }}$ November}

Afghanistan launched its bid to join the World Trade Organization (WTO), senior advisor to President Hamid Karzai and minister of commerce Hedayat Amin Arsalan announced. (SAN $\Lambda$ )

\section{$21^{\text {st }}$ November}

Afghanistan's southern Kandahar province is all poised to export more than 1,260 tons of fresh and dry fruit to a number of countries in the next few days. (Online)

\section{$22^{\text {nd }}$ November}

The foreign exchange reserve of Afghanistan has reached $\$ 1.5$ billion, a figure unregistered in the past. (NNI)

\section{$26^{\text {th }}$ November}

Reconstruction of the main airport of Gardez has been completed and its capacity enhanced.
An a resalt, large uheralt for domestic fiphts (ail use it. (SANA)

\section{$27^{\text {th }}$ November}

Afghanistan's leading Telecom Development Company Afghanistan (Roshan), claims that its GSM subscriber base reached 650,000 this month. (INP)

\section{$30^{\text {th }}$ November}

Iran and Afghanistan are ready to boost joint investment by cooperation of their respective private sectors in mineral, steel, profile, construction, rug, food and other indusries. (Agencies)

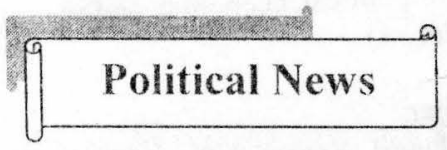

\section{$2^{\text {nd }}$ November}

President Karzai was under growing pressure on Tuesday to intervene in the case of an editor jailed for two years for blasphemy after clerics accused him of questioning Islamic law. (Online)

\section{$5^{\text {th }}$ November}

Iranian President Ahmadi Nezhad and his Afghan counterpart Hamid Karzai discussed mutual as well as regional developments over phone. (NNI)

\section{$13^{\text {th }}$ November}

President Hamid Karzai Saturday urged Taliban fighters and other militants to abandon their insurgency against his government and US-led forces in Afghanistan and join a national reconciliation process. (Reuters)

\section{$14^{\text {th }}$ November}

The head of Afghanistan's reconciliation commission accused forces in Pakistan Sunday of propping up a deadly insurgency being waged in the name of loyalists of the Taliban government ousted four years ago. (AFP) 
Afghanistan is to join the Sou'h Asian Association for Regional Cooperation (SAARC). India Prime Minister Manmohan Single told the closing session of the $13^{\text {th }}$ SA $\triangle R C$ summit. (Agencies)

\section{$15^{\text {th }}$ November}

President Hamid Karzhi headed to Austria Monday for a conference on Islam with other Muslim leaders and would afterwards visit Franee for talks on European assistance towards war ravaged Afghanistan. (AFP)

\section{$16^{\text {th }}$ November}

Taliban fighters rejected overtures from Afghan President Hamid Karzai to abandon their insurgency and join a reconciliation process. (Reuters)

\section{$19^{\text {th }}$ November}

The European Union and Afghanistan on Wednesday signed a joint declaration on a new partnership between the two sides. which aims to deepen bilateral ties. (NNI)

The United Nations and the UK will co-chair and international conference in Iatc January to give global support to Afghanistan as its first representative government starts tackling a wide range of political, economic, and security issues. (Agencies)

\section{$21^{\text {st }}$ November}

President Hamid Karzai led administration formally began a weeklong accountability. In line with president's order the accountability week Saturday and would continue till November $24^{\text {th }}$. (Online)

\section{$29^{\text {th }}$ November}

The post-war Afghanistan would present its National Development Strategy at the next donor's conference in London, Afghan Foreign Minister said. (SANA)

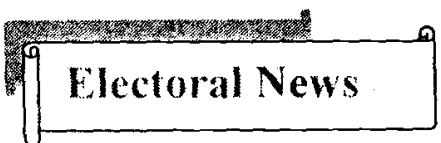

\section{$1^{\text {st }}$ November}

Latif Pedram the leader of the Afghan National Congress Party says the government was involved in fraud during the parliamentary election. (NNI)

\section{$5^{\text {th }}$ November}

The final results from Afghanistan's first legislative election for more than three decades well are announced this Wednesday after delays due to fraud complaints. (AFP)

\section{$\underline{8}^{\text {th }}$ November}

Afghanistan's former President Burhanuddin Rabbani. hinted to run for the post of head of Wolusi hirga. or Speaker of the National Assembly. (NNI)

\section{$10^{\text {th }}$ November}

The release of final results from landmark legislative elections held last Scptember has been postponed because investigators are still studying allegations of widespread cheating in southern Afghanistan. (AP)

\section{$13^{\text {th }}$ November}

The results of parliamentary elections were finalized Saturday after cight weeks of counting showed by allegations of fraud and observers said supporters of President Hamid Karzai appeared to be in the majority. $(\Lambda P)$

\section{$21^{\text {st }}$ November}

JEMB has announced that Ghazni provincial Shura has failed to nominate representatives for parliament at time when it has been summoned to meet. (Online)

\section{$27^{\text {th }}$ November}

The United Nations Assistance Mission in Aighanistan has announced that the new Aighan Parliament's first session is to be held in December 2006. (Online)

\section{$30^{\text {th }}$ November}

The UN Security Council congratulated Afghanistan on the formal acceptance of clection results that ivill seat a new parliament. (PPI)

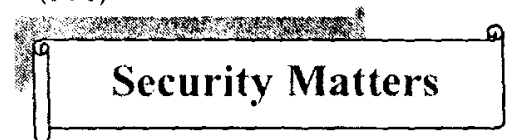

\section{$1^{\text {st }}$ November}

A civilian was killed in a bomb blast probably targeted a US convoy in castern Afghanistan on Monday, while security forces foiled a suicide attack on forcign troops. (AFP)

\section{$2^{\text {ntl }}$ November}

Two Afghan men clearing hundreds of mines littering runways around Afghanistan's main airport were killed when one of the devices exploded. (AFP)

\section{$3^{\text {rd }}$ November}

Taliban killed five Afghan policemen in an ambush in the restive southern province of Helnand. (Reuters)

\section{$5^{\text {th }}$ November}


Taliban militants in Afghanistan on Friday attacked a police station in Abband district. Ghazni Province and killed a policeman. (NNI)

\section{$8^{\text {th }}$ November}

A woman poet well known in litcrary circles in Afghanistan's western city of Harat has died after being severely beaten by her husband. who has been arrested. (AFP)

\section{$10^{\text {th }}$ November}

Afghan and US-led forces have arrested a suspected would be suicide bomber who is allegedly from a Pakistan tribal region. (AFP)

\section{$11^{\text {th }}$ November}

Taliban militants killed seven policemen and beheaded two civilians, while an A fghan soldier was shot dead after he opened firc on US troops. (AFP)

\section{$13^{\text {th }}$ November}

Suspected Taliban killed three policemen and former district chief in a mosque in fresh attacks in troubled Afghanistan. ( $\mathrm{AFP}$ )

\section{$14^{\text {th }}$ November}

Taliban militants killed three policemen and stole their vehicle in an attack in Afghanistan's volatile south. (AFP)

\section{$15^{\text {th }}$ November}

Four people including a German soldier and three Afghan civilians were killed when twin suicide bombs exploded Monday on the capital Kabul an Interior Ministry said.

\section{$17^{\text {th }}$ November}

Three civilians were killed and four other people wounded when an explosive packed car rammed a US-Afghan military convoy in a

- suicide attack Wednesday. (AFP)

\section{$18^{\text {th }}$ Novernber}

Security forces killed three Al-Qaeda suspects. a provincial governor said Thursday, while the country's defense minister warned that militants have smuggled explosives, weapons and cash into Afghanistan for a resurgent terror campaign. (Agencies)

\section{$19^{\text {th }}$ November}

A Portuguese soldier was killed Friday and three others were wounded when an explosion struck their vehicles outside Kabul. ( $\Lambda$ gencies) $20^{\text {th }}$ November

28 Taliban and Islamic fighters surrendered to authorities in insurgency hit Afghanistan and renounced any anti government activities. (AFP)

\section{$21^{\text {st }}$ November}

Taliban insurgents have kidnapped an Indian road engineer in southern Afghanistan in Nimroze Province. (Agencies)

\section{$25^{\text {th }}$ November}

Afghan police yesterday found the body of an Indian construction worker M.R Kutty, dumped by the roadside with his throat siashes after he was kidnapped by suspected Taliban. (PPI)

\section{$26^{\text {th }}$ November}

A Swedish soldier serving with NATO-led International Security Assistance Force has died from his injuries after being evacuated from an incident where he and three other occupants of an ISAF vehicle were caught in an explosion in Mazar-e-Sharif yesterday.

\section{$27^{\text {th }}$ November}

Afghan troops foiled a bomb attack in the capital Kabul on Saturday with the arrest of six suspected militants and their explosives packed vchicle. (AFP)

At least twenty rockets werc fired last night at Sharana, capital of Paktika Province, killing personnel of intelligence department and damaging governor house. (Agencies)

\section{$29^{\text {lit }}$ November}

At least two people were killed and ten others were injured in clashes between two armed groups in Faryab Province. (Agencies)

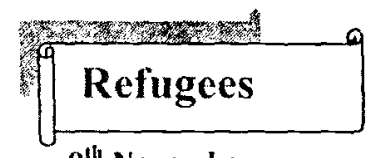

\section{$9^{\text {th }}$ November}

Political administration here Tuesday launched a crackdown against $A$ fghan nationalists residing illegally in different villages and towns of North Waziristan Agency.

\section{$11^{\text {th }}$ November}

In a crackdown against Afghan refugees, the political administration Thursday deported 45 more Afghan nationals, who were residing in difierent towns of NWA.

\section{$12^{\text {tit }}$ November}

Pakistan hosting 3 million Afghan refugees, the 17 percent of the world's refugees population. told the United Nations. (APP)

\section{$18^{\text {th }}$ November}

Political administration of Kurram Agency has * restarted repatriation of $A$ fghan refugees living 
in the area and dozens of families have been trucked to their homeland via Rabbani Churiel.

\section{$24^{\text {th }}$ November}

High Commissioner of UN Agency for Refugees UNHCR Antonio Gutcres has arrived in Afghanistan to discuss with Aghan president the life of returnees. (Online)

\section{$26^{\text {th }}$ Novenuber}

In the continuation of the repatriation of Afghan refugees, some 750,000 have returned home so far in the current year. (NNi)

\section{$27^{\text {tli }}$ November}

The UN High Commissioner for Retuges: (UNHCR) Antonio Guterres Friday night assured the Afghan refugees that they would not be forcefully repatriated to their comtry unless they themselyes opt for it. (NPP)

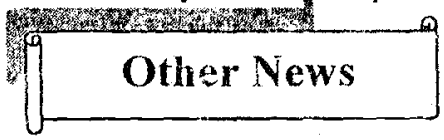

\section{$2^{\text {nd }}$ November}

Afghan authorities say they have destroyed 30 opium processing laboratories as well as tones of drugs and chemicals used to make heruin. (Online)

\section{$3^{\text {rd }}$ November}

A Japanese artist is to recreate Afghanistan's destroyed Bamiyan Buddhas using dozens of laser beam image. (Online)

\section{$10^{\text {th }}$ November}

Russia's federal drug control service will open oftices in several countries including Afghanistan, next year. (SANA)

\section{$11^{\text {th }}$ November}

- Afghanistan has banned duck hunting and imports of live poultry to prevent the spread of the deadly bird flu virus, Public llealth Ministry Sayed Mohd Amin Fatimi said on Tuesday. (Reuters)

\section{$26^{\text {th }}$ November}

A narcotics survey has revealed that almost one million people in Afghanistan take drugs; seven percent of them are children. (INi) 